\title{
Vertebral Numbers in Atlantic Cod, Gadus morhua, of the Newfoundland and Adjacent Areas, 1947-71, and Their Use for Delineating Cod Stocks
}

\author{
Wilfred Templeman \\ J. L. Paton Chair of Marine Biology and Fisheries \\ Memorial University of Newfoundland \\ St. John's, Newfoundland, Canada
}

\begin{abstract}
A total of $416 \mathrm{cod}$ vertebral samples collected from the Newfoundland and adjacent areas during 1947-71, are analyzed in relation to their use for delineating the cod stocks of the region. Differences greater than two vertebrae were found between the highest and lowest vertebral means for different stocks. The overall vertebral mean for females exceeded that for males by 0.10 .

The main portion of the Labrador-East Newfoundland stock (Div. $2 \mathrm{G}$ to $3 \mathrm{~K}$ ) was well separated from the southern Grand Bank stock (Div. $3 \mathrm{~N}$ and 30 ) by the presence in the northern area of high vertebral means and of higher percentages of high vertebral numbers and the lack of low vertebral numbers. This contrasted with vertebral means about one to two vertebrae lower in the southern Grand Bank stock, with higher percentages of low vertebral numbers and a lack of high vertebral numbers. Cod from the offshore area in Div. $2 G$ to $3 K$ had somewhat higher vertebral numbers than those of the inshore area. The high vertebral-count cod of the Labrador-East Newfoundland stock also extended to the northern slopes of Grand Bank and around the Avalon Peninsula (Div. $3 \mathrm{~L})$, but in this area they usually intermingled with cod of the Avalon stock complex and with some migrants from southern Grand Bank as indicated by vertebral means intermediate between the northern and southern extremes. In the Labrador-East Newfoundland stock, vertebral means were slightly lower in 1961-71 than in 1947-60. Vertebral means for cod off West Greenland were considerably lower than those for Labrador cod and similar to those for the southern Grand Bank stock. On St. Pierre Bank (Subdiv. 3Ps), some samples had as low vertebral means as those on Grand Bank whereas other samples had intermediate vertebral means similar to those in the adjacent coastal area. The northern Gulf and southern Gulf stocks, north and south of the Laurentian Channel in the Gulf of St Lawrence (Div. 4RST), had low vertebral means, except for evidence of the intrusion of some cod with high vertebral numbers in and near the Strait of Belle Isle. Vertebral means declined from north to south on the Scotian Shelf (Div. 4VWX) and to Georges Bank (Div. $5 Z$ ).
\end{abstract}

Spawning times of cod in various parts of the Northwest Atlantic are reviewed, and vertebral numbers for the different areas and stocks are related to the surface temperatures and current drifts following spawning. The lowest surface temperatures during egg and early larval development were associated with the longest period of egg and larval drift, the highest vertebral means, and the largest, most-widely distributed stock.

\section{Introduction}

The division of cod stocks in the western North Atlantic was discussed by Hansen (1949) for West Greenland, by Templeman (1953, 1962b, 1974, 1979), Fleming $(1958,1960)$ and Templeman and Fleming (1962) for the Labrador and Newfoundland areas, by Martin (1953), McKenzie and Smith (1955) and McKenzie (1956) for the Gulf of St. Lawrence and Scotian Shelf areas, by Wise (1963) for the Gulf of Maine and Georges Bank areas, and by Wise and Jensen (MS 1960) and Templeman (1962b) for the whole Northwest Atlantic region. The evidence used in these papers was one or more of migratory studies, growth patterns and vertebral numbers. Inferences regarding stock divisions and migrations of cod in a large part of the area off eastern Canada can also be drawn from the distribution of cod containing the nematodes Terranova (= Porrocaecum) decipiens and Anisakis sp. (Templeman et al., 1957) and the copepod Lernaeocera bran- chialis (Templeman and Fleming, 1963; Templeman et al., 1976), and from biochemical methods (Jamieson, 1975; Cross and Payne, 1978). Schmidt (1930) and Stanek (MS 1968) indicated the usefulness of finray counts (2nd dorsal), but these may be better as an accessory to rather than a replacement for vertebral numbers in the delineation of most stocks.

For cod of the Newfoundland and adjacent areas (Fig. 1), vertebral averages have been reported by Schmidt (1930), Thompson (1943), Postolaky (1962), and Stanek (MS 1968). The samples were not numerous or well distributed enough to be of much assistance in the detailed delineation of the stocks but were sufficient to show that differences as great as two vertebrae existed between the averages for cod off Labrador and on the southern Grand Bank. Other studies on vertebral numbers in cod are those by Schmidt (1930) and Hansen (1949) for West Greenland, by McKenzie $(1939,1940)$ for the Scotian Shelf, and by McKenzie 


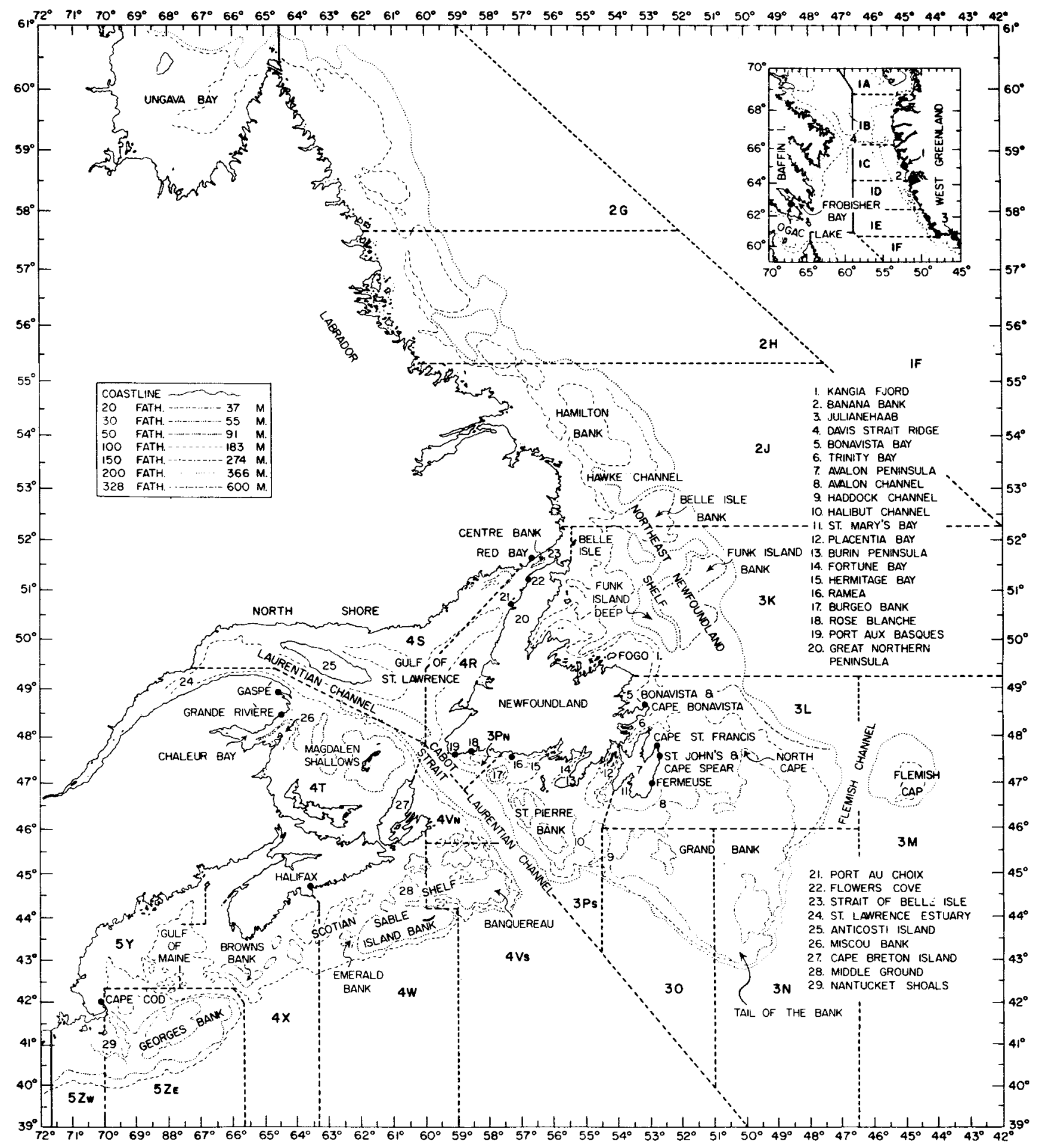

Fig. 1. Map showing the NAFO divisions and the place names mentioned in the text.

and Smith (1955) for St. Pierre Bank, Gulf of St. Lawrence, Scotian Shelf and Bay of Fundy. Comparisons of vertebral means for cod from the same areas in the Northwest Atlantic show relatively small variations in vertebral numbers from Schmidt's (1930) samples of 1923-29. Thompson's (1943) samples of 1931-35 and
Hansen's (1949) samples of 1924-37 to those of the 1947-60 and 1961-71 periods presented in this paper. Portions of the data used in this paper were referred to previously in papers by Templeman $(1953,1962 \mathrm{~b}$, 1979), Fleming (1958, 1960), Pinhorn (1970) and Lear et al. (MS 1979). 
The purpose of this paper is to describe and explain the resemblances and differences in cod vertebral numbers from a large number of samples collected throughout the Northwest Atlantic region and to indicate how the information relates to current knowledge on stock location, boundaries and intermingling, derived from other sources, especially migration studies.

\section{Materials and Methods}

As an aid to studying the delineation of cod stocks in the Newfoundland and adjacent areas, 416 cod vertebral samples were collected in 1947-71. Most of the samples were randomly selected from commercial and research vessel catches, but some samples collected in recent years by length categories were included. Attempts were made to collect 120 specimens from each locality, so that at least 100 specimens would remain after allowing for discarding of vertebral columns due to breakage and fusions. This was not always possible on research vessel surveys when catches were small. However, only 4 of the 416 samples contained fewer than 52 specimens.

After recording certain biological data, including fork length to the nearest $\mathrm{cm}$ and the sex, the fish were filleted, the remains boiled briefly, the flesh cleaned off thoroughly with a pressure hose, and the vertebral columns dried in a small salt-fish dryer. The vertebral counts were made independently by two laboratory technicians and checked by another technician or a biologist experienced in counting vertebrae and detecting fusions. Also, the author made a final check by examining $5-10 \%$ of the specimens, usually at random, and all specimens with fusions and with very high or very low counts.

The vertebral counts were made according to the North American practice of omitting the urostylar halfvertebra (McKenzie and Smith, 1955; Templeman, 1962b). However, Schmidt (1930) and Postolaky (1962) included the urostylar half-vertebra in their counts. Thompson (1943), Hansen (1949) and Stanek (MS 1968) did not state their counting method. Thompson, in correspondence with the author about 20 years ago, indicated that he did not remember his counting method but presumably used the European practice of including the urostylar half-vertebra. Hansen (1949) compared his cod vertebral counts and averages directly with those of Schmidt (1930) and Thompson (1943), so that he apparently used the same method. Comparison of vertebral averages reported by Thompson, Hansen and Stanek with those of samples for the same areas in the present study indicates that they included the urostylar half-vertebra in their counts. In this paper, in the interest of uniformity with the European practice, the vertebral averages are based on counts which include the urostylar half-vertebra as a vertebra. The vertebral counts for the small numbers of skeletons with fused vertebrae are not included in the analyses.

The distribution of vertebral means of individual samples and their lower and upper extremes have many advantages (which will become apparent as the data are presented) for outlining the limits of the cod stocks and their intermingling. In samples from such a large area, the variances may be unequal, in which in case an approximate $t^{\prime}$ test of significance of the difference between means should be used (Sokal and Rohlf, 1969). However, with samples as large and variances as low as in the cod vertebral samples presented in this paper, the question of unequal variances can usually be neglected, as the difference between means for any two samples with unequal variances is only slightly greater than if the variances of the samples were equal, for a particular level of significance. For example, using the approximate $t^{\prime}$ test for samples of 51 and 121 fish, whose vertebral means have the same standard error $( \pm 0.10)$, the difference between means for significance at $P=0.05$ is 0.282 , compared with 0.279 if the variances were equal. Likewise, for two samples of 101 fish each, with standard errors of \pm 0.12 and \pm 0.16 , the difference between vertebral means for significance at $P=0.05$ is 0.397 , compared with 0.394 for samples with equal variances. Nearly all of the samples contained 52 or more fish and the standard errors of the means were usually between \pm 0.07 and \pm 0.12 but occasionally as high as \pm 0.16 . Thus, whether variances are equal or unequal, a difference of 0.40 between vertebral means will usually be significant at the $P=$ 0.05 level, and differences as low as 0.20 may be significant for samples with the lowest standard errors. With the means and standard errors given in Fig. 3 and 5 , approximate $t$ and $P$ values can be quickly calculated mentally. For pairs of vertebral means, $t \geqslant 2.0$ indicates significance of the difference at $P=0.05$, and $t \geqslant 2.7$ indicates significance at $P=0.01$. Where there are large numbers of high vertebral-count samples in one area and low vertebral-count samples in an adjacent area, a smaller difference between means would be significant by the combination of samples for each area to give higher numbers of specimens and lower standard errors.

\section{Results}

\section{Vertebral means of male and female cod}

For 364 samples, in which there were at least 30 specimens of each sex, the frequency distribution of the difference between vertebral means of male and female cod, arranged by intervals of 0.040 such that the 0 -interval was -0.019 to +0.019 , ranged from -0.640 to +0.540 and was reasonably normal with mean of -0.036 
TABLE 1. Comparison of vertebral means of male and female cod by period and area.

\begin{tabular}{|c|c|c|c|c|c|c|c|c|}
\hline \multirow[b]{2}{*}{ NAFO Subarea } & \multicolumn{2}{|c|}{ No. of cod } & \multicolumn{2}{|c|}{ Vertebral mean } & \multicolumn{2}{|c|}{ Standard error } & \multirow{2}{*}{$\frac{\text { Difference }}{(M-F)}$} & \multirow[b]{2}{*}{$P$} \\
\hline & Mate & Female & Male & Female & Male & Female & & \\
\hline \multicolumn{9}{|c|}{ A. Period 1947-60 } \\
\hline 2. Labrador & 2,593 & 2,946 & 55.276 & 55.295 & 0.017 & 0.016 & -0.019 & 0.40 \\
\hline 3. Newfoundland & 6,168 & 6,810 & 54.471 & 54.595 & 0.015 & 0.014 & -0.124 & $<0.001$ \\
\hline 4. Gulf of St. Lawrence & 1,520 & 1.474 & 53.922 & 54.077 & 0.027 & 0.029 & -0.155 & $<0.001$ \\
\hline 4. Scotian Shelf & 318 & 303 & 54.211 & 54.254 & 0.048 & 0.046 & -0.043 & 0.50 \\
\hline All Areas & 10,599 & 11,533 & 54.581 & 54.699 & 0.011 & 0.011 & -0.118 & $<0.001$ \\
\hline \multicolumn{9}{|c|}{ B. Period 1961-71 } \\
\hline 1. West Greenland & 770 & 732 & 53.610 & 53.686 & 0.031 & 0.031 & -0.076 & $>0.05$ \\
\hline 2. Labrador & 2,680 & 2,672 & 55.181 & 55.177 & 0.016 & 0.015 & +0.004 & $>0.80$ \\
\hline 3. Newfoundiand & 6,996 & 7,308 & 54.468 & 54.599 & 0.013 & 0.013 & -0.131 & $<0.001$ \\
\hline 4. Gulf of St. Lawrence & 847 & 989 & 54.161 & 54.222 & 0.038 & 0.035 & -0.061 & $>0.20$ \\
\hline All Areas & 11,293 & 11,701 & 54.566 & 54.642 & 0.011 & 0.010 & -0.086 & $<0.001$ \\
\hline \multicolumn{9}{|c|}{ C. Period 1947-71 } \\
\hline 1. West Greenland & 770 & 732 & 53.610 & 53.686 & 0.031 & 0.031 & -0.076 & $>0.05$ \\
\hline 2. Labrador & 5,273 & 5,618 & 55.228 & 55.239 & 0.009 & 0.009 & -0.011 & $>0.30$ \\
\hline 3. Newfoundland & 13,164 & 14,118 & 54.469 & 54.597 & 0.010 & 0.010 & -0.128 & $<0.001$ \\
\hline 4. Gulf of St. Lawrence & 2,367 & 2,463 & 54.007 & 54.135 & 0.022 & 0.022 & -0.128 & $<0.001$ \\
\hline 4. Scotian Shelf & 318 & 303 & 54.211 & 54.254 & 0.048 & 0.046 & -0.043 & 0.50 \\
\hline All Areas & 21.892 & 23,234 & 54.568 & 54.670 & 0.008 & 0.007 & -0.102 & $<0.001$ \\
\hline
\end{tabular}

and standard error of 0.010 , implying that the mean of the differences deviated significantly from zero $(P$ $<0.01)$. The vertebral mean for females exceeded the mean for males in 205 samples and vice versa in 159 samples. Deviation from the $50: 50$ ratio was significant $(0.01<\mathrm{P}<0.02)$ by the chi-square test.

The vertebral means of male and female cod were compared by NAFO subarea for each of the 1947-60 and 1961-71 periods (Table 1). In 7 of the 8 cases, the mean for females exceeded that for males, the differences being highly significant $(P<0.001)$ for the Newfoundland area in both periods and the Gulf of St. Lawrence in the earlier period and for the period totals. When the data for the two periods were combined, the mean for females exceeded that for males in all cases, significantly so for the Newfoundland and Gulf of St. Lawrence areas and for the period total.

Although there is an apparent difference between vertebral means of males and females for each period and for certain regions, most of the differences are not significant when the data are considered on a sample basis. Because of this and because the samples contained approximately equal numbers of both sexes, the data for males and females were combined for comparison of individual samples, which is the chief method used in this paper.

\section{Mean vertebral numbers}

Cod vertebral means, presented in this paper, ranged from 53.22 to 55.62 , thus reflecting great variation from one part of the Northwest Atlantic to another.
Aithough moderately sharp divisions between adjacent areas of high and low vertebral-count fish were sometimes evident from the data, some relatively unmixed schools of high vertebral-count fish appear to intrude into areas occupied by low vertebral-count fish and vice versa. Consequently, much information, which would be obscured by combination of samples, can de derived by examining the distribution of individual samples. Because of the long period under investigation and the possibility of detecting changes in vertebral means due to changes in climate and fishing activity, this study covers two periods, 1947-60 and 1961-71

Period 1947-60. Throughout the area covered by the cod samples collected in this period, (Fig. 2 and 3 ), vertebral averages ranged from a high of 55.62 off Labrador (Div. 2H) to a low of 53.30 on the southern Grand Bank (Div. 3N). In some parts of the region there was little variation in mean vertebral counts over great distances, whereas in other parts there was moderately sharp distinction between areas with high and low vertebral averages.

Mean vertebral numbers over the area from Ungava Bay and Labrador to the northern Grand Bank (Div. 2G, 2H, 2J, 3K and northwestern part of Div. 3L) were typically higher than 55 (Fig. 3 ). The cod in this large area, with the highest vertebral numbers in the Northwest Atlantic, constitutes the Labrador-East Newfoundland stock (Templeman, 1962b, 1974, 1979). Relatively undiluted schools of these high vertebralcount fish showed slight penetration on the eastern side of the Strait of Belle Isle to Port au Choix, as 
indicated by three samples with vertebral means of $55.06,54.86$ and 54.66. Schmidt (1930) also reported a high vertebral mean of 55.46 for a sample taken in August-September 1923 on the eastern side of the Strait of Belle Isle at Flowers Cove. It is also likely that the two samples with vertebral averages of 54.70 and 54.36 from the central part of the northeastern Gulf of St. Lawrence show the effect of intermingling of high vertebral-count fish, which migrated into the Gulf along the southern side of the Strait of Belle Isle, with lower vertebral-count fish of the northern Gulf stock. Off Labrador and Northeast Newfoundland, the samples from inshore areas had, on the average, slightly lower vertebral means than those from offshore areas.

The high vertebral-count cod extended southward to the northern edge of the Grand Bank, beyond which in a southerly direction over the shallow central part of the bank there was increasing evidence of mixing of these fish with low vertebral-count fish of the southern Grand Bank stock. However, relatively unmixed schools of high vertebral-count fish appear to have migrated along the eastern slope of the Grand Bank as far south as $45^{\circ} 30^{\prime} \mathrm{N}$ (Div. $3 \mathrm{~N}$ ), as evidenced by a sample with a vertebral mean of 55.28. Postolaky (1962) reported a similar example of small cod with high vertebral counts in the northern part of Div. 3N. In coastal waters of eastern Newfoundland, cod with high vertebral counts formed a large part of most samples as far south as St. John's, but half of the St. John's samples had vertebral means below 55, indicating some intermingling with southern low vertebral-count fish.

The Grand Bank area, south of $46^{\circ} \mathrm{N}$ and east of $54^{\circ} 30^{\prime} \mathrm{W}$ (i.e. Div. $3 \mathrm{~N}$ and $3 \mathrm{O}$ ), is occupied mainly by the southern Grand Bank stock of cod with vertebral means typically below 54 . The most representative part of this stock, showing less intermingling with other stocks, is along the southern and southeastern parts of the bank. The two samples with high vertebral means (54.79 and 55.28) in the northeastern part of Div. 3N indicate intrusion of some fish of the Labrador-East Newfoundland stock. Another sample with a moderately high vertebral mean $(54.48)$ in the northern part of Div. 30 also indicates a mixture of low and high vertebral-count cod.

Vertebral averages for samples from the western part of the Grand Bank, the Avalon Channel, the Avalon Peninsula, Placentia and Fortune bays and vicinity were typically intermediate, i.e. between 54 and 55. Tagging studies (Templeman and Fleming, 1962; Templeman, 1974,1979 ) have shown that the small cod populations in this area (Avalon stock complex) intermingle with each other and also with high and low vertebral-count fish of the Labrador-East Newfoundland and southern Grand Bank stocks respectively, which migrate to the area. Offshore samples from St.
Pierre Bank (Subdiv. 3Ps) indicate considerable variation in vertebral averages, some being slightly above 54 , similar to those of samples taken in coastal waters of this subdivision, and others being below 54, similar to those of the southern Grand Bank stock in Div. $3 \mathrm{~N}$ and 30 .

In the Gulf of St. Lawrence, the vertebral averages of the northern Gulf cod stock (north of the Laurentian Channel) were typically below 54 , except in the northeastern part of the Gulf where high vertebral means (54.7-55.1) indicated intermingling with the LabradorEast Newfoundland stock. In Subdiv. 3Pn, where much of the northern Gulf stock spends the winter (Templeman, 1974, 1979; Templeman and Fleming, 1962), all vertebral averages were below 54.50 and some were below 54. South of the Laurentian Channel in the Gulf of St. Lawrence, all of the vertebral means were below 54.51 , with half of them being below 54 .

The small amount of data from the Scotian Shelf confirmed the general picture from earlier studies by McKenzie and Smith (1955). All of the samples from Sable Island Bank northward had vertebral means above 54, whereas those taken south of that bank were all below 54, indicating rather distinct stocks on the northern and southern parts of the Scotian Shelf. The two samples from Georges Bank had vertebral means below 54.

Period 1961-71. Throughout the area covered by the cod samples collected in this period (Fig. 4 and 5), vertebral averages ranged from a high of 55.59 off Labrador (Div. 2J) to a low of 53.22 on the southern Grand Bank (Div. 3N). The broad picture of cod vertebral averages in the Labrador and Newfoundland areas for this period was essentially the same as that described for 1947-60, except that vertebral means in cod off Labrador and eastern Newfoundland and on the northern Grand Bank in 1961-71 were, on the average, lower and those along the southwestern slope of Grand Bank slightly higher than in 1947-60. On Flemish Cap, the vertebral means in 1961-71 were essentially the same as those in 1947-60. In the Gulf of St. Lawrence, samples from western Newfoundland and the North Shore of the Gulf westward from $60^{\circ} \mathrm{W}$ had vertebral means typical of the northern Gulf stock (less than 54), whereas samples from the northern side of the Strait of Belle Isle with high vertebral means (54.78-55.24) indicated the penetration of schools of the Labrador-East Newfoundland stock on the northern side of the Strait of Belle Isle. On the other hand, a sample from the central part of the Strait of Belle Isle had a vertebral mean of 53.96, typical of the northern Gulf stock.

Samples of cod taken off West Greenland in August 1965 had vertebral means (53.48-53.97) similar 


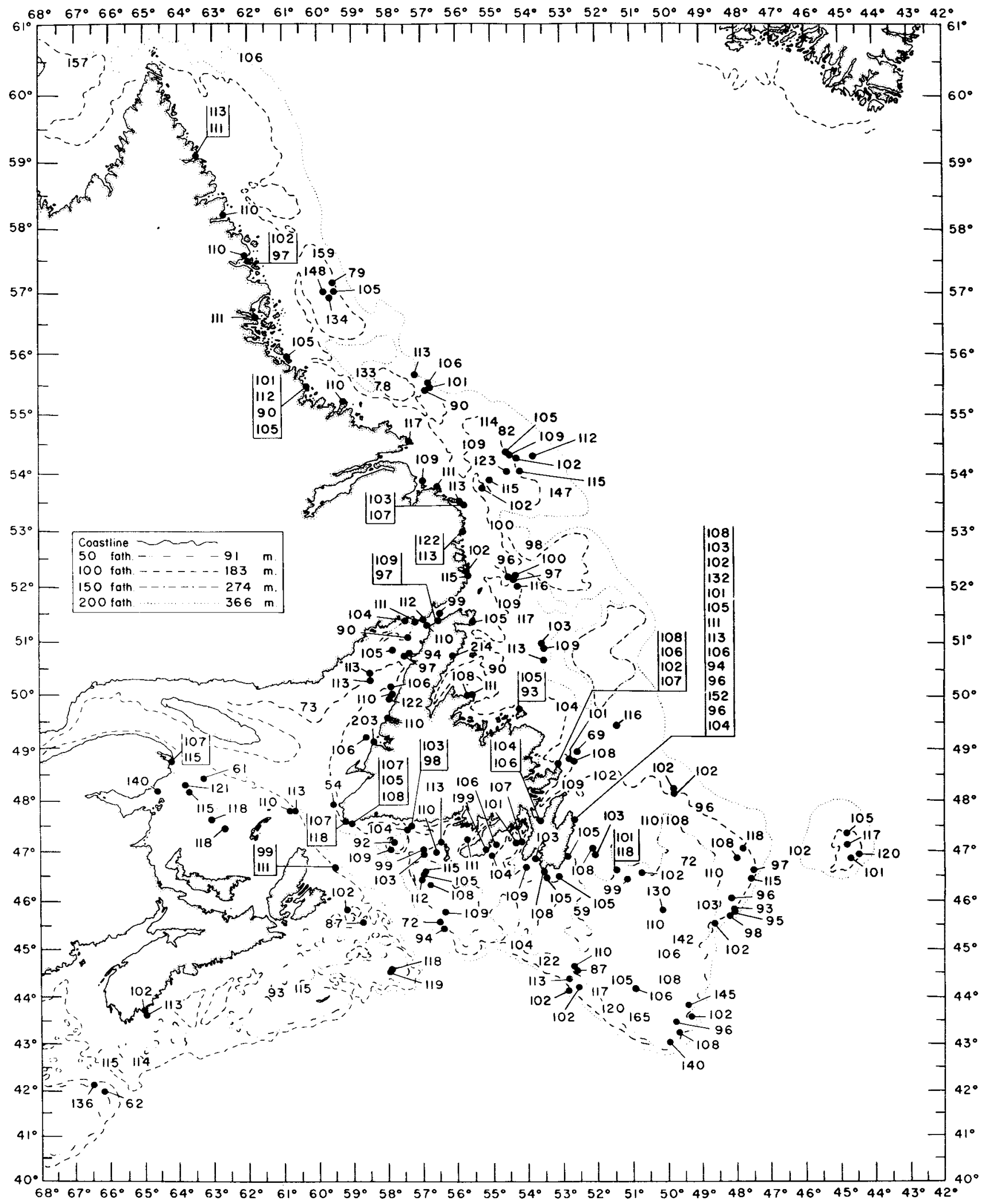

Fig. 2. Number of cod vertebral columns applicable to the vertebral means and percentages of low and high vertebral numbers in Fig. 3,6 and 8 for the $1947-60$ period. 


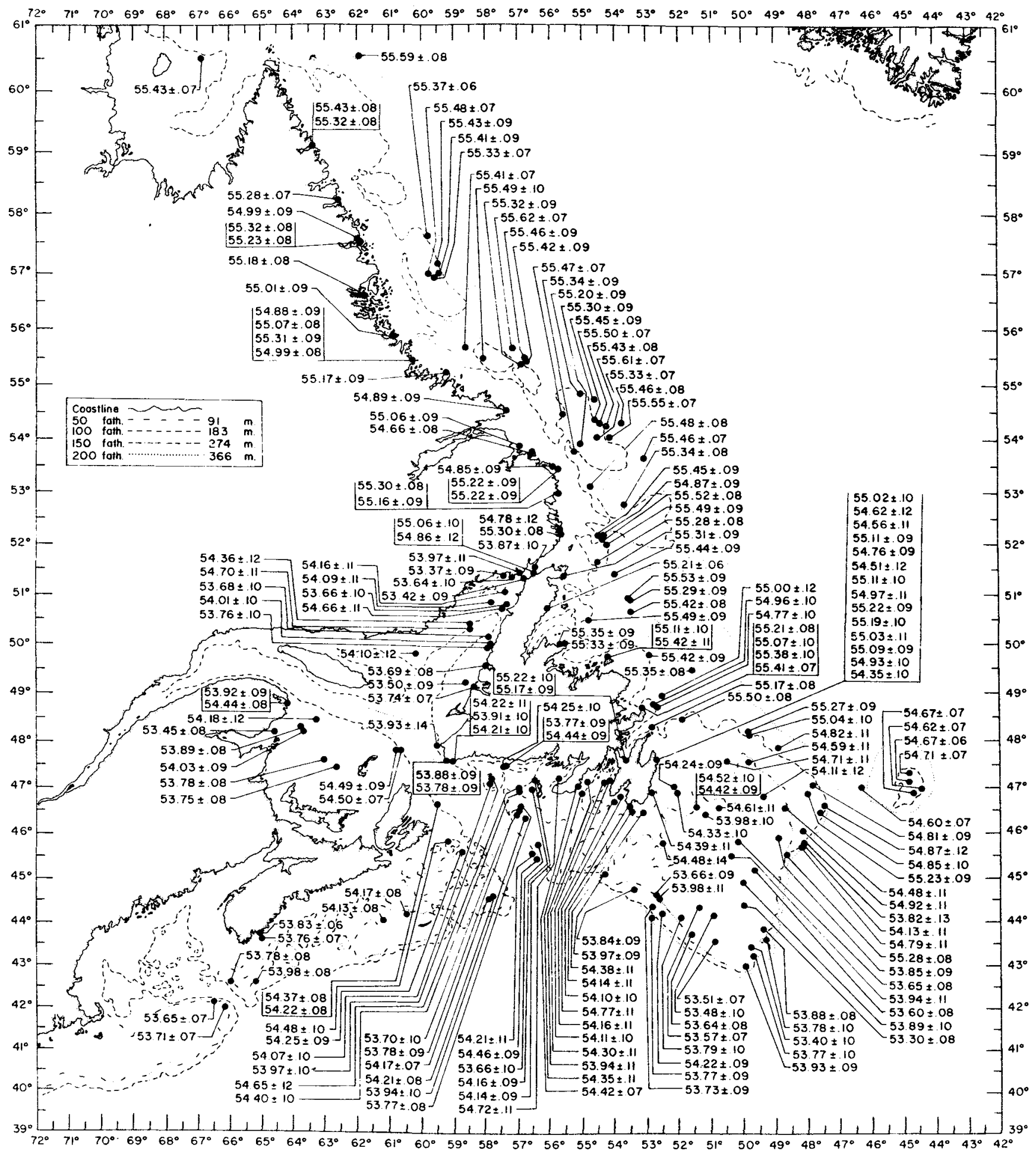

Fig. 3. Vertebral means (including the urostylar half-vertebra) and standard errors for the samples in Fig. 2 for the $1947-60$ period.

to those of the southern Grand Bank stock and much lower than those of the Labrador-East Newfoundland stock. Although only five samples were available, the vertebral averages showed a declining trend from north to south. These data confirmed the picture of vertebral means presented by Hansen (1949) from investigations in 1924-37.
Patriquin (1967) reported a vertebral average of 53.14 (including the urostylar half-vertebra) for a sample of cod from a small relict population in Ogac Lake, a land-locked fiord on the southern side of Frobisher Bay in Baffin Island. Although the actual vertebral counts were not included in his paper, Patriquin (pers. comm.) indicated that the vertebral counts for 77 Ogac 


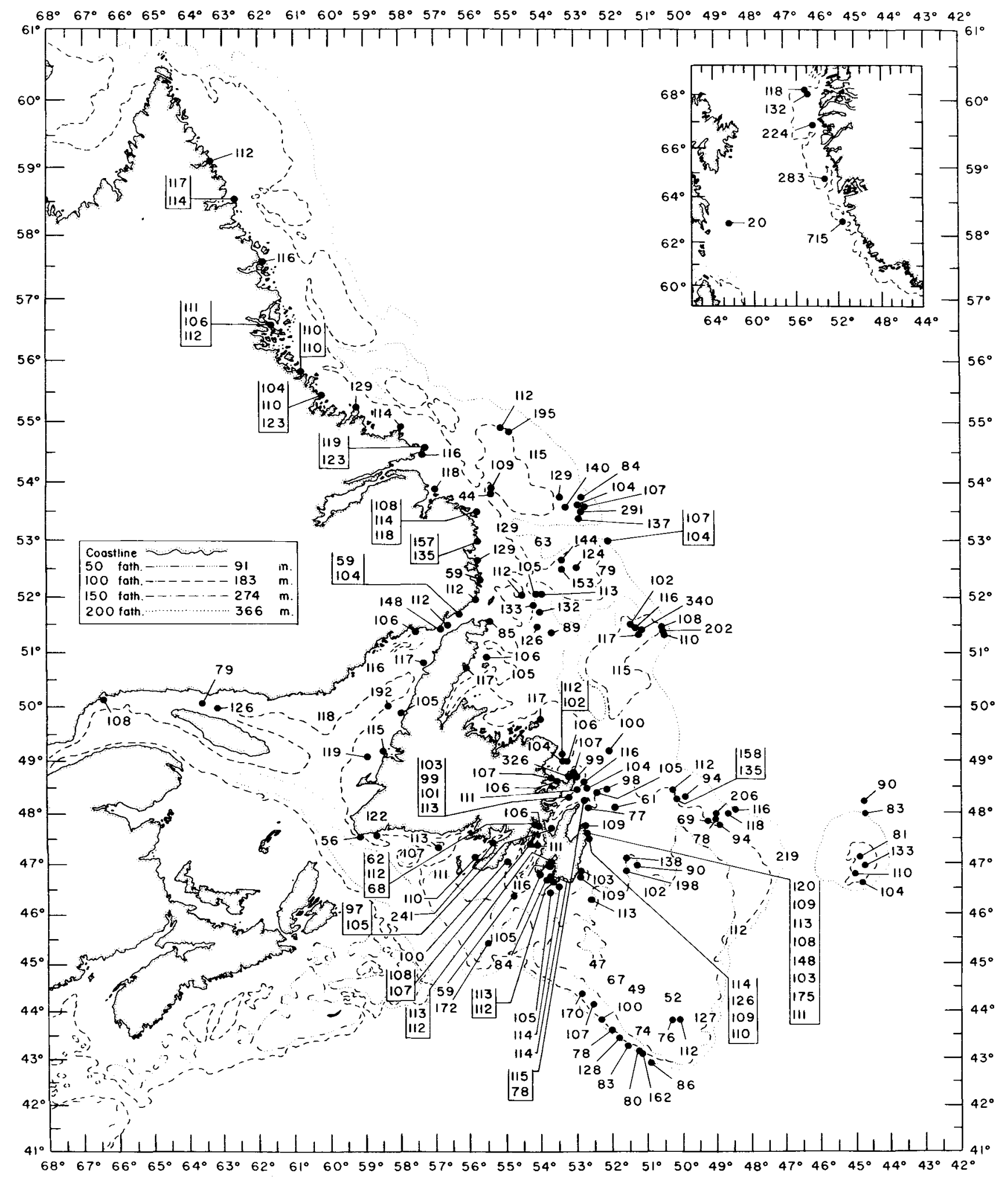

Fig. 4. Numbers of cod vertebral columns applicable to the vertebral means and percentages of low and high vertebral numbers in Fig. 5,7 and 9 for the 1961-71 period. 


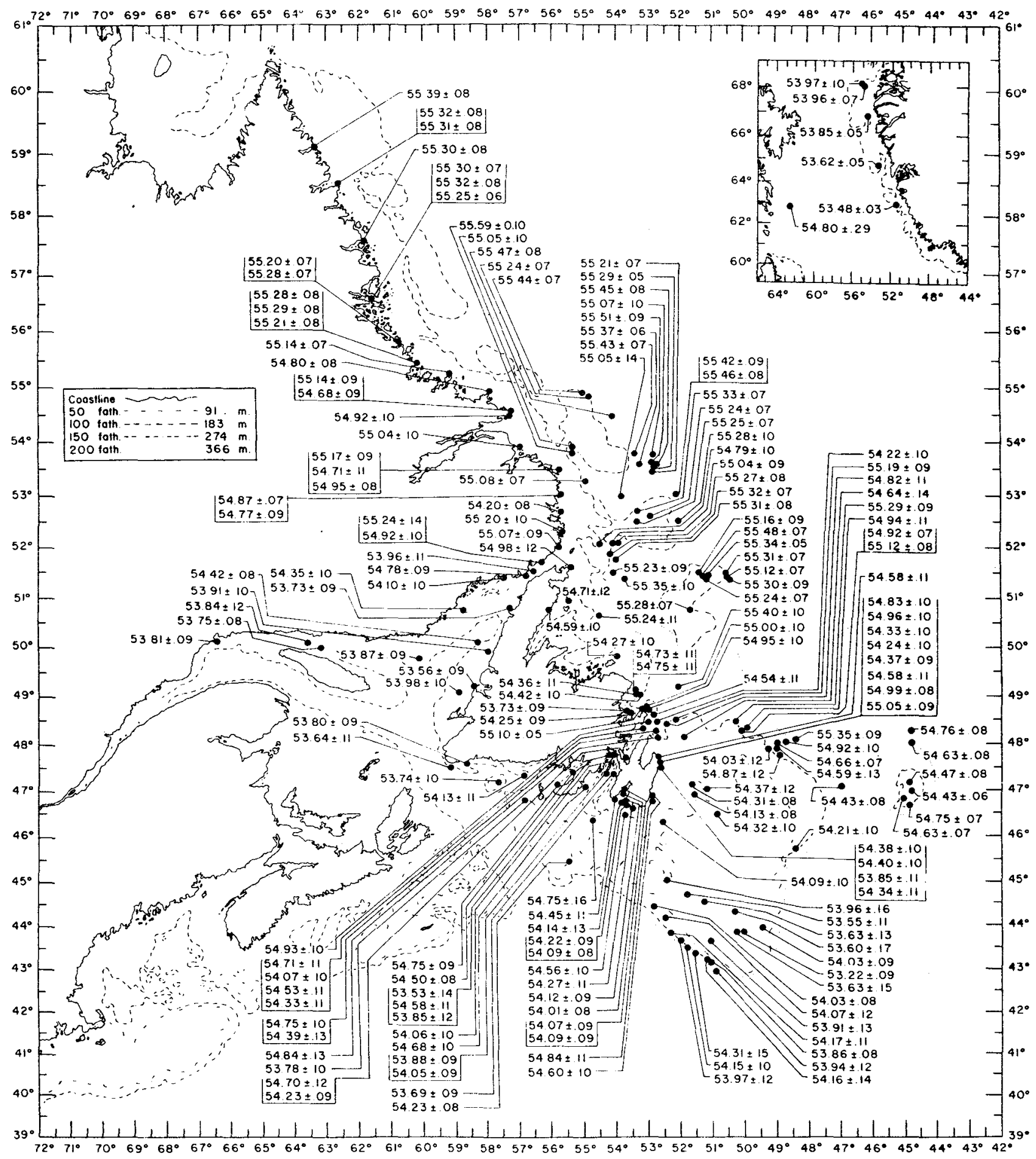

Fig. 5. Vertebral means (including the urostylar half-vertebra) and standard errors for the samples in Fig. 4 for the 1961-71 period. (For convenience in relation to the data for West Greenland, the small Baffin Island sample taken in 1959 is included in this Figure and in Fig. 4, 7 and 9.)

Lake cod were 52(10), 53(48) and 54(19), with mean and standard error of $53.12 \pm 0.07$. He stated that the slight difference in the means may be due to the inclusion of some additional specimens in his 1967 paper.
Statistically, the vertebral mean of the Ogac Lake cod sample is significantly lower $(P<0.001)$ than those for the adjacent West Greenland, Ungava Bay and northern Labrador areas (Fig. 3 and 5). 
The vertebral mean (54.80) of a small sample of 20 cod taken off Frobisher Bay, Baffin Island, in 1959 (Fig. 5) was lower than those for northern Labrador and higher than those for West Greenland, but the small sample size and the very large standard error (0.29) associated with this mean makes a statistical comparison with those of adjacent areas unrealistic.

\section{Low vertebral numbers (50-52)}

Low vertebral numbers (Fig. 6 and 7) are useful as natural tags to show migration or lack of migration between areas with differing distributions of vertebral numbers. Low vertebral numbers (50-52 vertebrae) were usually absent, or occurred occasionally as $1 \%$ of a sample, in cod of the Labrador-East Newfoundland stock from Ungava Bay and northern Labrador to the northern slope of Grand Bank. The most consistent lack of these low vertebral numbers was in samples from the offshore areas of Labrador and Northeast Newfoundland Shelf and from the inshore areas of northern Labrador. However, especially in the 1961-71 period (Fig. 7), some samples with higher percentages of 50-52 vertebrae were taken near the coast southward of Hamilton Inlet in Labrador and along eastern Newfoundland. Some relatively undiluted samples of the Labrador-East Newfoundland stock, with 50-52 vertebrae constituting 0 or $1 \%$, were taken as far south as St. John's in both periods and Fermeuse in 1961-71 and also around the eastern edge of Grand Bank to near $45^{\circ} 30^{\prime} \mathrm{N}$ in Div. 3N. Samples from West Greenland had distinctly higher percentages of low vertebral numbers than most samples off Labrador and Northeast Newfoundland.

Most of the samples from the southern Grand Bank had considerably higher percentages (up to $20 \%$ ) of cod with 50-52 vertebrae, but those along the northeastern, northern and northwestern slopes of the bank with lower percentages indicated dilution with the Labrador-East Newfoundland stock. The cod samples from St. Pierre Bank had similarly high percentages of fish with 50-52 vertebrae except for one sample with $0 \%$.

The cod samples of the coastal and near coastal areas from the southern part of the Avalon Peninsula westward along southern Newfoundland typically had intermediate percentages ( $3-7 \%$ ) with $50-52$ vertebrae, but there were three samples in Placentia Bay with higher percentages and two samples with $0 \%$.

Cod samples from the northern Gulf of St. Lawrence stock, north of the Laurentian Channel, typically had intermediate percentages with low (50-52) vertebral numbers, but a few samples had percentages almost as high as the highest in the southern Grand Bank samples. The penetration of the Labrador-East
Newfoundland stock into the northeastern part of the Gulf is apparent in or near the Strait of Belle Isle where $0-3 \%$ of the fish in some samples had $50-52$ vertebrae.

Cod with 50-52 vertebrae were absent in 11 samples of the Flemish Cap stock which is isolated from the cod populations on the Grand Bank.

\section{High vertebral numbers (57-59)}

High vertebral numbers, also useful as natural tags, presented a reverse picture to that for low vertebral numbers (Fig. 8 and 9 ). These high numbers were absent in all of the West Greenland samples and in most of those from the southern Grand Bank, whereas most of the samples taken in the region from northern Labrador to the northern slope of the Grand Bank offshore and to St. John's in coastal waters had 4-11\% of the fish with 57-59 vertebrae. These differences clearly differentiated the West Greenland and the Labrador-East Newfoundland stocks and indicated the area of overlap of the Labrador-East Newfoundland and the southern Grand Bank stocks. The occurrence of high vertebral numbers showed, even more clearly than vertebral averages, the area of intermingling in Div. 3L, mainly along the slopes of the Grand Bank and shoreward in coastal waters of the Avalon Peninsula. In this area, many of the samples had intermediate percentages of cod with 57-59 vertebrate, resulting from the mixture of high and low vertebral-count fish of the northern and southern stocks respectively. The southern Grand Bank stock, represented typically by samples with 0 and $1 \%$ of $57-59$ vertebrae, extended from the southern slopes of the bank northward over the shallow plateau and was found occasionally in unmixed schools on the northern slope. The Flemish Cap percentages (0-2\%) were distinctly lower than those of the Labrador-East Newfoundland stock predominant along the slopes of the adjacent northeastern Grand Bank.

Low percentages (usually $0 \%$ ) of cod with $57-59$ vertebrae also occurred on St. Pierre Bank and occasionally in inshore areas of southern Newfoundland, although some samples from the latter region had higher percentages $(2-7 \%)$. The great variation in percentages along southern Newfoundland and the proximity of this region to St. Pierre Bank and to the area of mixing of low and high vertebral-count fish off southeastern Newfoundland makes it difficult to delineate these stocks from the percentage occurrence of high (57-59) vertebral counts.

The northern Gulf of St. Lawrence stock is typified in samples with low percentages (0-2\%) of cod with 57-59 vertebrae along southwestern and western Newfoundland, in the Strait of Belle Isle, and along the North Shore of the Gulf. However, in the northeastern 


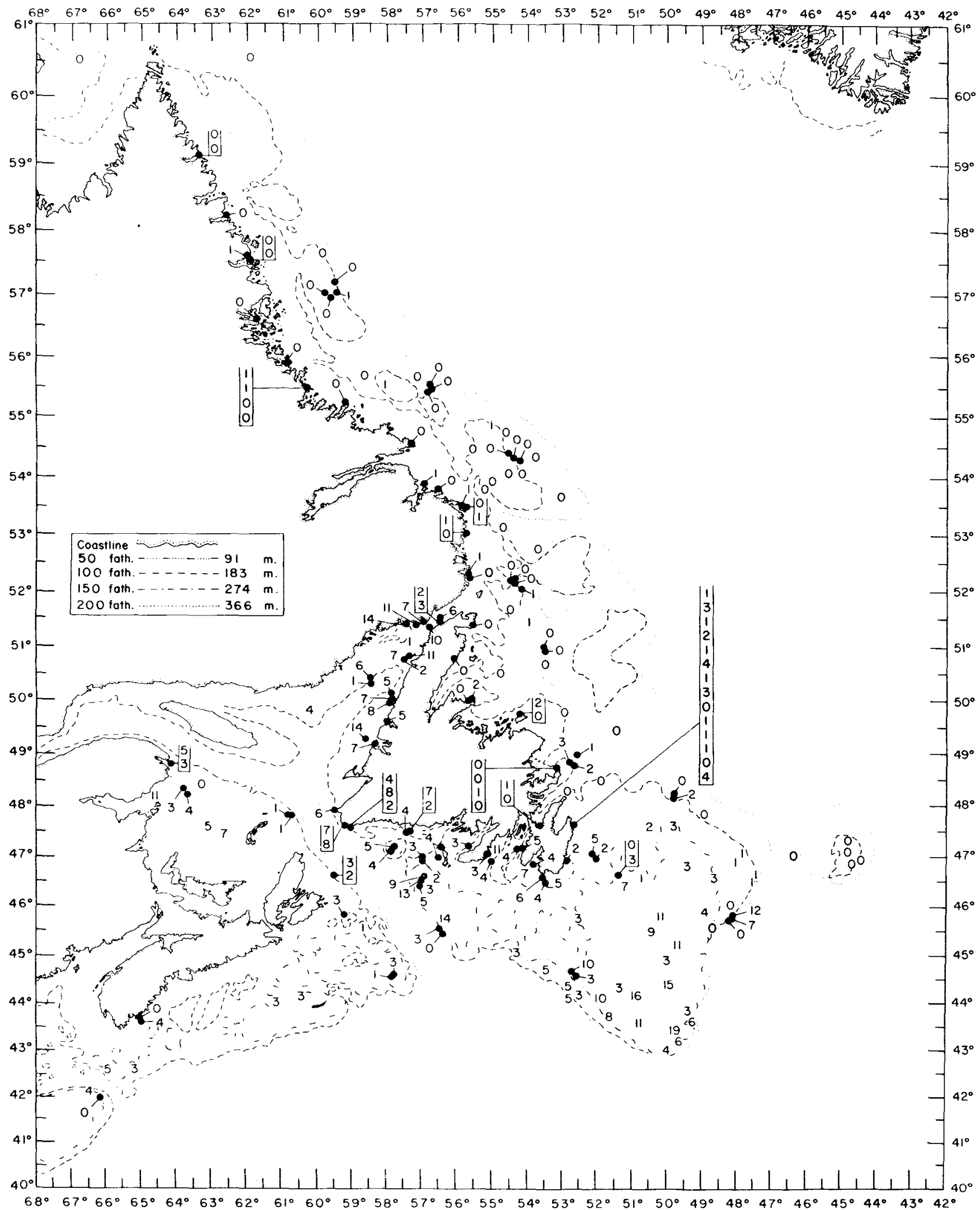

Fig. 6. Percentages of cod with low vertebral numbers (50-52) in the samples of Fig. 2 and 3 for the 1947-60 period. 


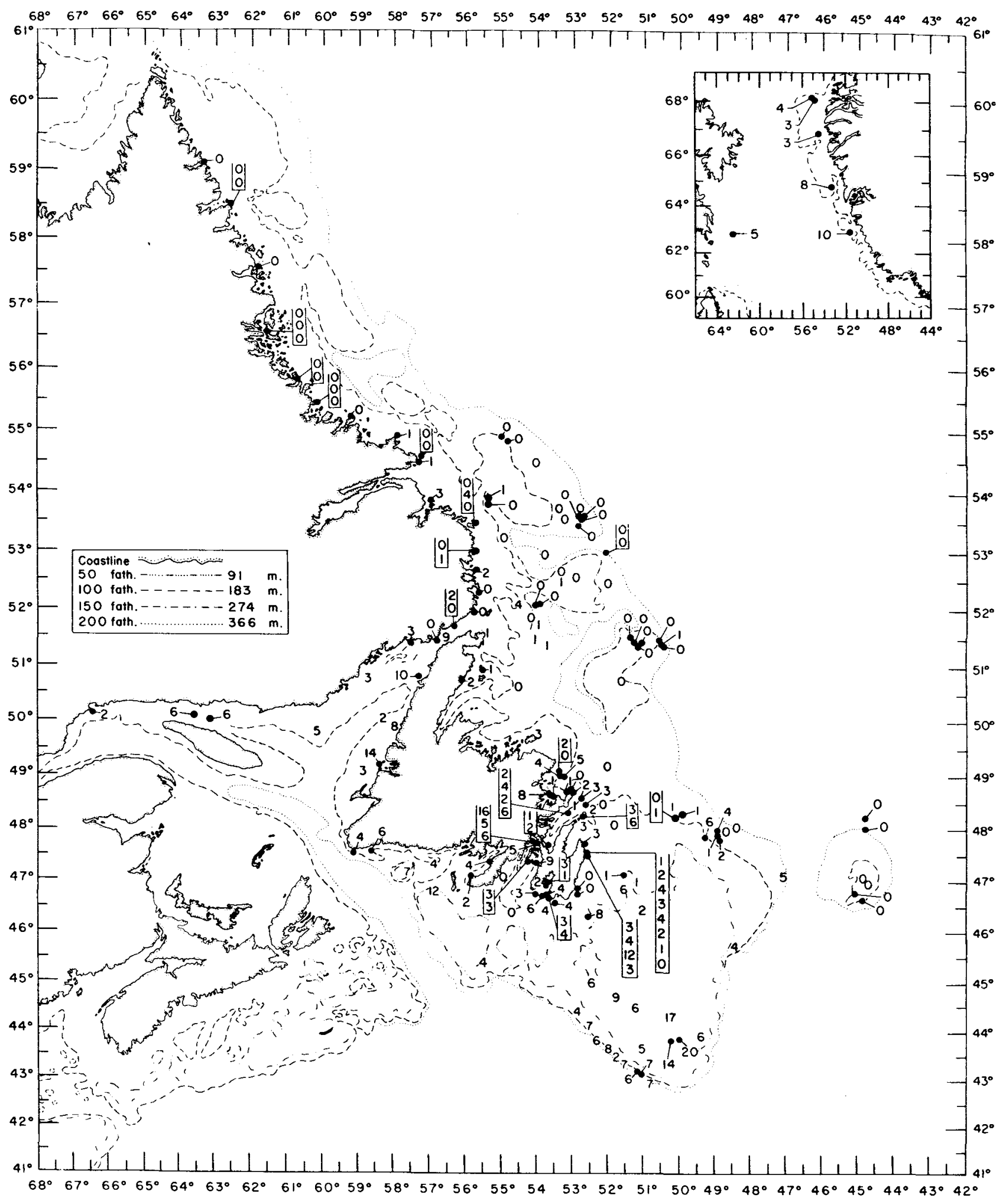

Fig. 7. Percentages of cod with low vertebral numbers (50-52) in the samples of Fig. 4 and 5 for the 1961-71 period. 


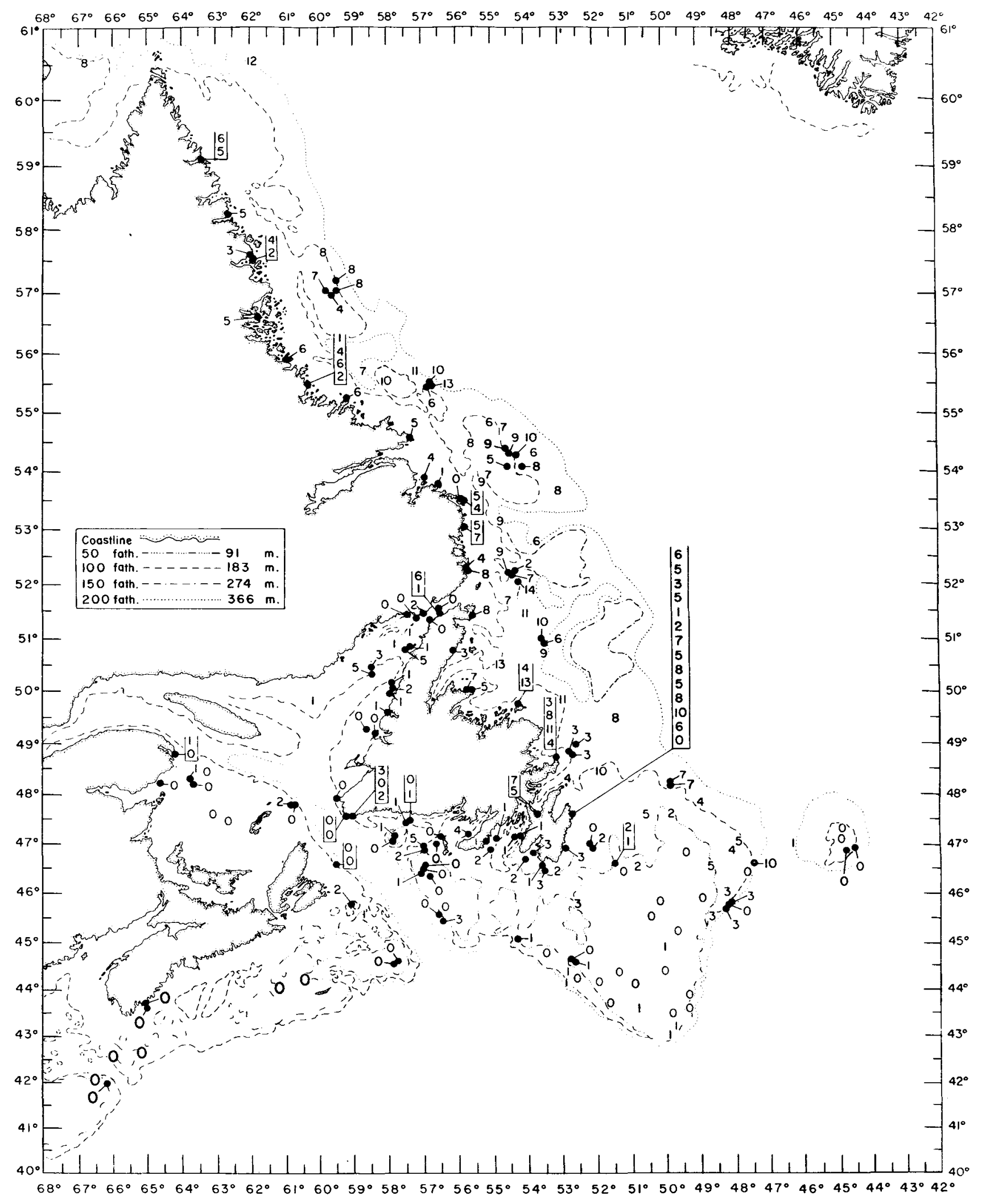

Fig. 8. Percentages of cod with high vertebral numbers (57-59) in the samples of Fig. 2 and 3 for the 1947-60 period. 


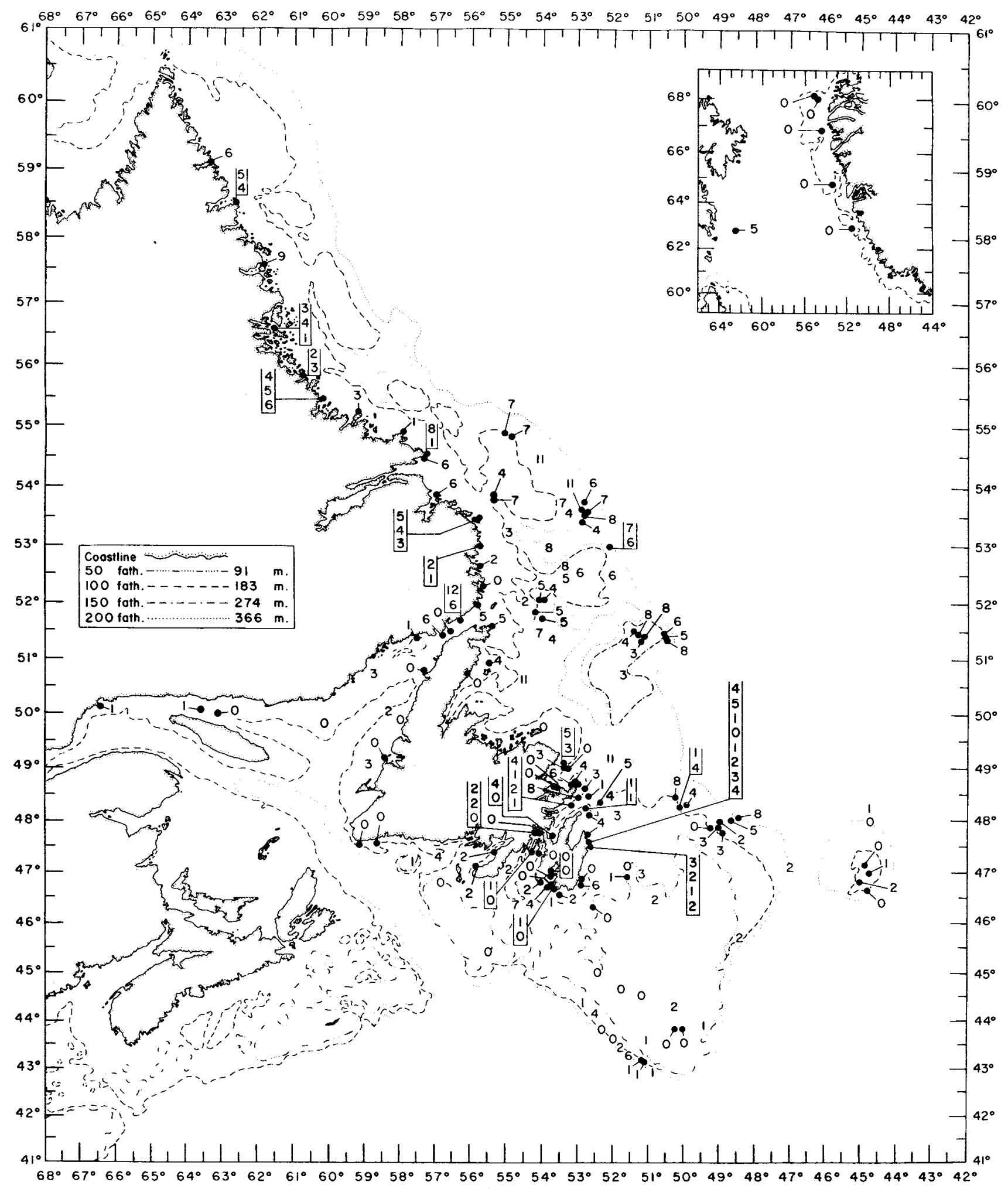

Fig. 9. Percentages of cod with nigh vertebral numbers (57-59) in the samples of Fig. 4 and 5 for the 1961-71 period. 
part of the Gulf and the Strait of Belle Isle, there were some samples with intermediate percentages (3-5\%), indicating a mixture of northern Gulf and LabradorEast Newfoundland fish, and some with higher percentages (6-12\%) typical of the Labrador-East Newfoundland stock. Percentages of these high vertebral numbers were $0-2 \%$ in samples from the southern Gulf of St. Lawrence and northern Scotian Shelf, and $0 \%$ on the remainder of the Scotian Shelf and on Georges Bank.

\section{Discussion}

\section{Vertebral means of male and female cod}

Although the vertebral mean was higher for female than for male cod, it is unlikely that this difference is genetically-related. In any one stock and area, females mature at a greater age and length than males and consequently grow faster at greater sizes (Hansen, 1949: Powles, 1958; Fleming, 1960). The fastestgrowing cod of both sexes probably have a tendency to mature earlier, as has been reported for haddock on Grand Bank and St. Pierre Bank (Templeman et al., 1978b; Templeman and Bishop, 1979a), on Georges Bank (Clark, 1959), in the North Sea (Raitt, 1933), and in the Barents Sea (Sonina, 1969). However, mature male cod remain in the spawning concentrations much longer than mature females (McKenzie, 1940; Chrzan, 1950; Thurow, 1970), and hence are subject to increased fishing mortality and possibly increased mortality due to reduction in feeding activity and increased energy expenditure for a longer period than females. Data presented by Hansen (1949, table 16) for cod of the northern and southern areas of West Greenland show that the percentage of females increased gradually from about $52 \%$ at ages $4-6$ in both areas to $56-57 \%$ at ages 10-14 in the northern area and to $59-65 \%$ in the southern area. The slightly greater vertebral means for females may therefore be due to the accumulated effect of slightly higher survival of females than males in the different year-classes in relation to the vertebral numbers. Although different migration patterns of males and females to and from areas of low or high vertebral-count fish could differentially affect the vertebral means of males and females in the samples from the different regions, the persistence of the higher vertebral means in females over both the 1947-60 and 1961-71 periods is evidence of a real difference. Such a difference might be expected if the vertebral pattern of females is more related than that of males to survival of the largest and fastest-growing members of a yearclass, and, by analogy with Pacific herring (Thompson, 1917; Hubbs, 1925; Tester, 1937; McHugh, 1942) and saithe (Dannevig, 1933), if these females have higher vertebral numbers due to hatching in the earlier part of the spring-early summer spawning period when temperatures are lower.

\section{Vertebral numbers and environmental factors}

The relation of vertebral numbers to various environmental factors was reviewed by Tåning (1952), Templeman and Pitt (1961), Lindsey (1961), and Fowler (1970). Under experimental conditions, meristic numbers may be modified during egg or early larval development by such factors as temperature, salinity, light intensity and duration, carbon dioxide and oxygen tensions, parasitic infection, and exposure to $X$ rays. Under natural conditions, meristic differences have usually been related to temperature, with the additional possibility of genetic effects. Schmidt (1930) indicated that water temperatures rather than low salinities influenced the vertebral numbers of cod in the eastern Baltic Sea, and that differences in the vertebral means of cod in the North Atlantic could be related to the surface temperatures of the various areas. Differences in temperature were related to changes in vertebral averages for Pacific herring by Rounsefell and Dahlgren (1932), Tester $(1937,1938)$ and McHugh (1942), for autumn-and spring-spawning cod off Nova Scotia by McKenzie (1940), and for cod of the North Atlantic by Brander (1979).

Under experimental conditions at different rearing temperatures, the curve of vertebral means in relation to temperature during egg and early larval development is generally $\mathrm{V}$-shaped or U-shaped, with the minimum at an intermediate temperature (Schmidt, 1921; Tåning, 1944, 1952; Lindsey, 1954, 1962a, 1962b; Molander and Molander-Swedmark, 1957; Seymour, 1959). However, the higher vertebral numbers caused by high temperatures are not as a rule evident in nature. It is possible that, under experimental conditions at high temperatures, there are other factors which retard development and thus increase vertebral numbers.

In experiments with sea-trout, Salmo trutta, Tåning $(1944,1952)$ found that the critical time for temperature effects on vertebral number was well before hatching, just before the development of eye-pigment in the larvae. Lindsey (1954), for the paradise fish, Macropodus opercularis, found that the vertebral number was subject to change up to 11-12 days after hatching. Molander and Molander-Swedmark (1957) concluded, from their experiments on European plaice, Pleuronectes platessa, that vertebral number was modified by changes in temperature up to at least 2 weeks after hatching. The sea-trout has a large egg with a long developmental period and a large larva at hatching, the paradise fish has an egg with very rapid development $\left(24\right.$ hours at $28^{\circ} \mathrm{C}$ ) and a small larva, and the plaice has a much smaller egg with more rapid development and a much smaller larva than the seatrout. The cod has a small egg with a moderately short developmental period and a relatively small but sturdy larva, and the determination of vertebral numbers 
should, by analogy with the above, occur before or shortly after hatching.

Apstein (1909) found that the development of cod eggs from fertilization to hatching takes about 60 days at $-1.0^{\circ} \mathrm{C}, 43$ days at $0^{\circ} \mathrm{C}, 33$ days at $1^{\circ} \mathrm{C}, 28$ days at $2^{\circ} \mathrm{C}, 23$ days at $3^{\circ} \mathrm{C}, 20$ days at $4^{\circ} \mathrm{C}, 18$ days at $5^{\circ} \mathrm{C}, 16$ days at $6^{\circ} \mathrm{C}, 13$ days at $8^{\circ} \mathrm{C}, 10$ days at $12^{\circ} \mathrm{C}$ and 8 days at $15^{\circ} \mathrm{C}$. Earll (1880) and Dannevig (1895) reported similar developmental periods over smaller temperature ranges.

Eggs and larvae of gadoid fishes are most common in the near-surface water layer. McKenzie (1940), for autumn-spawning cod off Nova Scotia, found $73 \%$ of the eggs in $0-2 \mathrm{~m}, 19 \%$ in $18-23 \mathrm{~m}$ and $8 \%$ in $30-48 \% \mathrm{~m}$, the majority of eggs from the deeper tows being in later stages of development than those taken in the surface layer. Wiborg (1948), for cod of the Lofoten area, found $81 \%$ of the eggs in the upper $25 \mathrm{~m}, 17 \%$ in $25-50 \mathrm{~m}$ and $2 \%$ in $50-100 \mathrm{~m}$. Wiborg (1950) found that the bulk of cod eggs and larvae in Westfjord, Norway, were in the upper $30 \mathrm{~m}$ (94\% of the eggs in 5-30 $\mathrm{m}$ and $6 \%$ in $35-50$ $\mathrm{m})$. Colton (1965) concluded that haddock eggs were concentrated in the surface layer, decreasing in abundance with increasing depth, and that the larvae and pelagic juveniles were concentrated within a limited depth stratum defined by the thermocline. In subsequent discussion on the relation of cod vertebral number to temperature and current systems in the Northwest Atlantic, most of the cod eggs and early larvae are assumed to be concentrated in the nearsurface layers.

\section{Relation of temperature and current systems to verte- bral numbers}

West Greenland. Cod spawning off West Greenland occurs mainly from March to June (Hansen, 1949; Meyer, 1962, 1967; Serebryakov, MS 1965). However, some of the cod from Southwest Greenland migrate to Southwest Iceland for spawning in March to May and return to West Greenland, as indicated by tagging experiments, and some of the larvae and fry from the Icelandic spawning areas are carried by the warm Irminger Current to East Greenland and presumably to Southwest Greenland (Tåning, 1937). There may also be egg and larval drift from East Greenland where cod spawning occurs in April and May (Serebryakov, 1967). From cod spawning grounds off Southwest Greenland, the eggs and larvae drift northward in the colder West Greenland Current. Upon reaching maturity, these cod migrate southward to spawn. Rasmussen (1959) found that, for cod tagged off West Greenland north of $66^{\circ} \mathrm{N}$ in July 1956, there was a northward migration in August-September, an overwinter migration southward, as far as $62^{\circ} \mathrm{N}$ for some fish, presumably for spawning, and a northward return during May-September in the year after tagging.
The vertebral numbers in cod of Southwest Greenland are slightly higher than those of East Greenland and somewhat higher still than those of Southwest Iceland (Schmidt, 1930; Hansen, 1949). The higher temperatures, encountered during the drift of eggs from Iceland to Southwest Greenland than during the drift of eggs from Southwest Greenland northward, presumably account for the lower vertebral numbers in the southern than in the northern West Greenland stock, as shown in this paper and by Hansen (1949) and Templeman (1962b).

Cod occasionally migrate from the Newfoundland area to West Greenland and vice versa (Templeman, 1974,1979 ). Also, in some years, especially 1957 , there was considerable drift of cod larvae from Greenland toward the coasts of Baffin Island and Labrador (Hansen, 1958; Hermann et al., 1965). Templeman (1961) concluded that young redfish, found off Baffin Island, could have drifted as young larvae from Iceland by way of West Greenland. However, the usual vertebral means above 55 off Labrador showed as great a distinction from West Greenland vertebral means as that between the Labrador and the southern Grand Bank vertebral means. As a possible exception, the small sample of cod taken off Baffin Island with a vertebral mean of 54.80 could have been a mixture of mainly cod with high vertebral numbers from northern Labrador and some with low vertebral numbers from West Greenland or Ogac Lake, in view of the large standard deviation associated with the sample.

Ogac Lake. Patriquin (1967) reported that cod spawning in Ogac Lake in 1962 occurred from late May to early July, and that temperatures recorded in 1957 for the $5-20 \mathrm{~m}$ depths inhabited by cod were $0.1^{\circ}$ to $7.1^{\circ} \mathrm{C}$ in early June, $3.1^{\circ}$ to $7.8^{\circ} \mathrm{C}$ in mid-July and $3.9^{\circ}$ to $8.9^{\circ} \mathrm{C}$ in mid-August. This relict cod population, with the lowest vertebral average (53.14) of any reported for cod of the Northwest Atlantic in the present paper, has been known to exist before 1927 (MCLaren, 1967), and it is apparent that the low vertebral numbers were due to high temperatures in the lake during egg and early development, rather than to the introduction of larvae from West Greenland, Labrador or Ungava Bay.

Labrador-East Newfoundland stock. This stock, extending from Ungava Bay and northern Labrador to the northern Grand Bank and the Avalon Peninsula, typically has the highest vertebral numbers in the Northwest Atlantic. Most of the spawning of this stock occurs during March-May (mainly March-April) in deep water along the slope of the continental shelf off Labrador (Div. 2GHJ) (Templeman, 1964, 1965; Noskov and Zakharov, 1964; Bogdanov et al., 1965, Dias, $1965,1967)$. There is also some later spawning in June in the colder water of the deep channels and bank slopes closer to the coast (Templeman, 1964; Chrzan, 
1968; Dias, 1972). Cod spawning off Northeast Newfoundland (Div. 3K), at least as far south as Funk Island Bank and vicinity, begins in March but occurs mainly in April to early May with some spawning continuing to June (Templeman, 1965, 1979; Dias, 1965). The evidence from egg surveys is that the greatest spawning occurs off northern Labrador (Div. 2G) (Serebryakov, 1967). Although most winter-spring catches from this stock have been in Div. $2 \mathrm{~J}, 65-81 \%$ of the cod tagged in May and $33 \%$ of those tagged in April on Hamilton Bank (Div. 2J) and on the Northeast Newfoundland Shelf (Div. 3K) were recaptured north of the tagging areas during the winter fishery in ensuing years (Templeman, 1979), indicating that spawning probably occurred north of the original tagging areas.

Surface temperatures above the areas inhabited by cod off Labrador are generally between $-1.5^{\circ}$ and $0^{\circ} \mathrm{C}$ in March to early May, slowly increasing to low positive values $\left(<1^{\circ} \mathrm{C}\right)$ in the southern part of the area by late May. Off northeastern Newfoundland (Div. 3K), surface temperatures are usually negative during the winter, slightly negative to $1^{\circ} \mathrm{C}$ in April and early May, and $0^{\circ}$ to $4^{\circ} \mathrm{C}$ in late May. The lower surface temperatures are found in the shoreward part of the Labrador Current and the higher temperatures seaward over the continental slope. Farther southward over the northern part of the Grand Bank (Div. $3 \mathrm{~L}$ ), $0^{\circ} \mathrm{C}$ temperatures are usual in March and early April, becoming slightly positive in May and June. In the colder shoreward part of the Labrador Current, even when the surface water begins to warm up, there is an intermediate layer of below $0^{\circ} \mathrm{C}$ water to a depth of $200 \mathrm{~m}$ or more (Templeman, 1962a; Templeman and May, 1965; unpublished data, Northwest Atlantic Fisheries Center, St. John's, Nfld.).

Considering the developmental periods from fertilization to hatching reported by Apstein (1909), cod eggs spawned off northern Labrador (Div. 2G) in March-April would take about 50-60 days to hatch in surface temperatures of $-1.5^{\circ}$ to $0^{\circ} \mathrm{C}$. Eggs spawned on the slopes of Hamilton Bank (Div. 2J) in March-April would take an average of about 40 days to hatch in temperatures of $-1^{\circ}$ to $1^{\circ} \mathrm{C}$. Because subsurface temperatures in these and later months are lower than at the surface, eggs distributed in subsurface layers would require correspondingly longer periods from spawning to hatching.

The speed of the Labrador Current, flowing southward off the coasts of Labrador and eastern Newfoundland, is not well known in winter and spring when the areas are covered with ice, most of the available information being from summer surveys. Mean velocities of 4-14 nauticai miles per day, usually $7-12$ miles per day, have been reported or used in describing the current at various sections from northern Labrador to St. John's (Iselin, 1930; Smith, 1931; Kiilerich, 1939; Buzdalin and Elizarov, 1962; Templeman, 1966; Serebryakov, 1967, Postolaky, MS 1975). At an average speed of about 10 miles per day, eggs spawned off northern Labrador would drift 500-600 miles southward to the area off southern Labrador by the time of hatching, and eggs spawned on the slopes of Hamilton Bank would drift about 400 miles to the northern Grand Bank and the Avalon Peninsula. Serebryakov (1967) reported that cod larvae appear in May off mid-Labrador and in April and May off southern Labrador.

During the long period of larval development at low temperatures, the pelagic cod larvae may be carried over great distances. In the Newfoundland area, the Labrador Current turns shoreward as it passes southward and brings large numbers of cod larvae into the large bays and numerous inlets of eastern Newfoundland, where they develop and uitimately settle to the bottom. Corlett (1958) reported, for three Northeast Atlantic stocks spawning in March, that North Sea cod settle to the bottom in early July at about 3.5 $\mathrm{cm}$, Icelandic cod in early August at about $4.5 \mathrm{~cm}$, and Arcto-Norwegian cod settle in the Barents Sea in late August and September at about $7.5 \mathrm{~cm}$, the larvae drifting in the coldest water and fry settling in the deepest areas having the longest pelagic life and consequently being more widely dispersed. In beach seining at 2-6 to $2-11 \mathrm{~m}$ for juvenile cod at various localities along eastern Newfoundland in September-October 1959-62, Fleming (MS 1963) reported catches of large numbers of age $0+\operatorname{cod}(1,400-4,800$ in different years) and found that the modes of the length frequencies ranged from 6 to $8-9 \mathrm{~cm}$, the smallest fish being usually $3-4 \mathrm{~cm}$ long. Some of the cod fry settle to the bottom in deep water away from the coast, as Bulatova (1962), from research trawling on the continental shelf and slope, found that juvenile cod less than $25 \mathrm{~cm}$ long were very abundant in Hawke Channel and on the northern fringe of Belle Isle Bank, with smaller numbers on the northern part of Funk Island Bank and on northeastern Grand Bank.

The early spawning and the prevailing low temperatures during the development of cod eggs and larvae, as they drift southward with the Labrador Current, produce the high vertebral numbers characteristic of the Labrador-East Newfoundland stock which predominates from Ungava Bay southward off Labrador and eastern Newfoundland and in the smaller fish to the northern Grand Bank and coastally to the St. John's area. This distribution also coincides with the migration picture, in which the cod of this stock, evidently resulting from spawning off Labrador and northeastern Newfoundland, migrate back when mature to spawn in these northern areas (Templeman, 1979). 
Southern Grand Bank stock. The most consistently low vertebral means, and the lowest proportions of high and the highest proportions of low vertebral numbers in cod of Subareas 2 and 3 (east of St. Pierre Bank) were found on the southern Grand Bank in Div. $3 \mathrm{~N}$ and $3 \mathrm{O}$. Some similarly low vertebral means were found on the plateau of the bank, but in the northwestern part of Div. 3O, the northeastern part of Div. $3 \mathrm{~N}$ and along the slope in Div. 3L there was intermingling with high vertebral-count fish of the northern stock. For example, on the northern slope of Grand Bank $\left(48^{\circ} 24^{\prime} \mathrm{N}\right.$. $\left.49^{\circ} 17^{\prime} \mathrm{W}\right)$ in March 1961 , cod taken in $180 \mathrm{~m}$ were mostly mature and had low vertebral numbers typical of the southern Grand Bank stock (Fig. 5), whereas mostly immature fish taken in 315-446 $\mathrm{m}$ had high vertebral numbers typical of the Labrador-East Newfoundland stock (Templeman, 1979). The main cod populations whose larvae populate Div. $3 \mathrm{~N}$ and 30 presumably spawn along the slope in Div. $3 \mathrm{~L}$ and $3 \mathrm{~N}$ and over the surface of the bank in Div. $3 \mathrm{~N}$ and 30 . On the northeastern Grand Bank (Div. 3L), spawning occurs mainly in April-June, but occasionally in years when temperature conditions are below normal spawning is delayed until May-July (Templeman, 1962a, 1979; Templeman and Fleming, 1962; Monteiro and Dias, 1964; Dias, 1968, 1971, 1972). On southern Grand Bank (Div. 3N, 3O), cod spawn mainly in AprilJune and usually in the latter half of April to early June (Templeman, 1962b; Rodriguez and Rojo, 1955; Rodriguez, 1956; Serebryakov, 1967; unpublished data Northwest Atlantic Fisheries Center, St. John's, Nfld.).

Data available for lines of stations running in a southwesterly direction across the southern part of the Grand Bank (Templeman et al., 1978a) indicated that surface temperatures ranged from $0.6^{\circ}$ to $3.6^{\circ} \mathrm{C}$ in late April 1964 and from $1.4^{\circ}$ to $4.6^{\circ} \mathrm{C}$ in early May 1965 , whereas in 1962 temperatures ranged from $1.4^{\circ}$ to $6.9^{\circ} \mathrm{C}$ in early May and from $3.9^{\circ}$ to $9.0^{\circ} \mathrm{C}$ in late May and early June. In all of these ranges, the lower surface temperatures were typically northward over the shallow areas of the bank and the higher temperatures over the southwestern slope. Buzdalin and Elizarov (1962) noted that the average temperature of the upper $50 \mathrm{~m}$ at $43^{\circ} \mathrm{N}$ in Div. $3 \mathrm{~N}$ was about $0.5^{\circ} \mathrm{C}$ in March 1960 . In view of the apparently higher surface temperatures during April to June in this area than farther north off Labrador and northeastern Newfoundland, the period from spawning to hatching of the eggs is correspondingly shorter, e.g. 28 days at $2^{\circ} \mathrm{C}, 20$ days at $4^{\circ} \mathrm{C}, 16$ days at $6^{\circ} \mathrm{C}$ and 13 days at $8^{\circ} \mathrm{C}$, according to Apstein (1909).

The main stream of the Labrador Current branches as it approaches the northern slope of the Grand Bank at about $50^{\circ} 30^{\prime} \mathrm{W}$ (Kudlo et al., 1980), the eastern branch flowing strongly along the northeastern and eastern slopes of the bank and the smaller western branch passing through the Avalon Channel. According to Buzdalin and Elizarov (1962), although velocities of about 2 nautical miles per day were evident along the eastern slope of the Grand Bank in February-April 1960, surveys in July-August of 1959 and 1960 indicated speeds of 13-16 miles per day along the northeastern and eastern slopes from $48^{\circ}$ to $45^{\circ} \mathrm{N}$ but only 5 miles per day on the southern part of the bank, where Kudlo et al. (1980) indicated the existence of slow clockwise eddies. The speed of the current flowing southward over the shallow parts of the bank is considerably slower than along the slopes. Thus, eggs spawned on the shallow parts of the Grand Bank, where surface water is relatively cold, tend to drift southward and at the time of hatching are located in the warm surface water over the southern slope of the bank. Eggs from low vertebral-count cod, which are frequently found and presumably spawn on the northeastern slope, are carried southward in the surface water of the eastern branch of the Labrador Current over a distance of perhaps 400 nautical miles to the southern tip of the bank where hatching occurs in relatively warm water. Serebryakov (1967) said that the eggs and larvae seem to be retained over the southern part of the bank by slow cyclical currents of 2-5 nautical miles per day. The haddock population on the southern part of the Grand Bank, before it declined to unexploitable levels in the early 1960's, was maintained by occasional very successful year-classes due to retention of larvae on the bank in the same years when good year-classes of cod appeared (May, 1965; Templeman et al., 1978a; Templeman, 1979).

In contrast to the conditions which produce the high vertebral numbers in cod of the Labrador-East Newfoundland stock, the later spawning and the higher temperatures during egg and larval development on the southern Grand Bank are evidently responsible for the lower vertebral numbers dominant in cod throughout most of Div. $3 \mathrm{~N}$ and $3 \mathrm{O}$.

Flemish Cap stock. Current and temperature conditions on Flemish Cap were reviewed by Templeman (1976) in relation to year-class survival of cod and redfish. The Flemish Cap Current, formed from the outer warmer fringe of the Labrador Current, passes over the northern slope and southward along the eastern slope of the bank. Near the southern slope, it merges with the mixed slope water of the northern fringe of the Atlantic Current, which flows past the southern slopes of Grand Bank and Flemish Cap in a northeasterly direction. On the central part of Flemish Cap, the water moves slowly in cyclonic and anticyclonic eddies, and there is normally a clockwise movement of water around the slopes of the bank (Smith et al., 1937; Buzdalin and Elizarov, 1962; Kudlo and Burmakin, 1972; Hill et al., 1975; Kudlo et al., 1980).

Cod spawning on Flemish Cap occurs from late February to May but mainly in March (Travin, 1959; Mankevich and Prokhorov, 1962; Templeman, 1962a, 
1969, 1976; Noskov et al., 1963; Dias, 1969; Serebryakov, 1967, MS 1978). Cod larvae were taken over the bank in April (Serebryakov, 1965, 1967). Surface water temperatures reported for this area generally range from $2^{\circ}$ to $7^{\circ} \mathrm{C}$ in March and April, increasing to $9^{\circ}-12^{\circ} \mathrm{C}$ in July (Templeman, $1959,1969,1973$; Movchan, 1967; Dietrich, 1960; Hill et al., 1975). Unlike conditions on the Grand Bank, cold Labrador Current water is not usually present over the Flemish Cap, and there is usually not much difference between the surface and deeper temperatures in March and April, although the surface layer warms up considerably by July. However, in occasional years (e.g. 1972), cold water of the Labrador Current extended eastward to Flemish Cap and was evident in the deeper layers on the bank in July (Templeman, 1973, 1975) but not in April when near bottom temperatures were above $3^{\circ} \mathrm{C}$ as usual and surface temperatures were $2^{\circ}$ to $3^{\circ} \mathrm{C}$ (Hill et al., 1975).

With spawning mainly in March and surface temperatures typically above $3^{\circ} \mathrm{C}$, hatching probably occurs in less than 23 days. The most intensive cod spawning is in deep water $(300-500 \mathrm{~m})$ on the southwestern slope of the Flemish Cap (Mankevich and Prokhorov, 1962; Noskovet al., 1963). The currents and eddies carry the eggs and larvae from the spawning areas on the slope toward the central part of the bank.

Although most of the cod on Flemish Cap spawn even earlier than those of the Labrador-East Newfoundland cod stock, the lower vertebral numbers in Flemish Cap cod are evidently due to higher temperatures during egg and larval development mainly in March and April. The vertebral averages were not, however, as low as those of the southern Grand Bank stock and were often not significantly different from the vertebral means in mixed samples of Labrador-East Newfoundland and southern Grand Bank cod found on the adjacent northeastern Grand Bank. The Flemish Cap Current system makes it unlikely that cod eggs and larvae from Flemish Cap are carried to adjacent areas, and similarly the Labrador Current and the North Atlantic Current fringing the Cap are not likely to contain many cod eggs and larvae from other areas. This probably explains the lack of variation in vertebral means and the unusual absence of low (50-52) and high (57-59) vertebral numbers in cod of this area.

Avalon stock complex. The cod stocks comprising this stock complex spawn chiefly during April to June (mainly in May and June on St. Pierre Bank, and mostly before June on the northwestern Grand Bank) on the slopes of the banks and in the channels extending from northwestern and western Grand Bank to Green Bank and St. Pierre Bank and in St. Mary's and Placentia bays, all under the influence of the western branch of the Labrador Current flowing southward through the
Avalon Channel and westward off southern Newfoundland (Templeman, 1979; Serebryakov, 1967).

Surface temperatures at Station 27 off St. John's are indicative of conditions on the western side of the Avalon Channel, averages for the 1950-59 period being $-0.8^{\circ} \mathrm{C}$ in March, $0.0^{\circ} \mathrm{C}$ in April, $2.1^{\circ} \mathrm{C}$ in May, $4.8^{\circ} \mathrm{C}$ in June and $9.9^{\circ} \mathrm{C}$ in July (Huyer and Verney, 1975). Comparable data for the northwestern Grand Bank in August had surface temperatures slightly higher than those at Station 27. Surface temperature data are rather scanty for St. Pierre Bank during the winter and spring months, but data from groundfish surveys in different months and years at various stations on the plateau and the western slope of the bank, as in Templeman and Bishop (1979b), indicate ranges of $0.9^{\circ}$ to $1.7^{\circ} \mathrm{C}$ in late March $1969,0.8^{\circ}$ to $3.1^{\circ} \mathrm{C}$ in late April $1967,3.5^{\circ}$ to $5.0^{\circ} \mathrm{C}$ in May $1968,4.4^{\circ}$ to $9.0^{\circ} \mathrm{C}$ in early June 1964 , and $6.3^{\circ}$ to $8.2^{\circ} \mathrm{C}$ in late June 1965 (unpublished data, Northwest Atlantic Fisheries Center, St. John's, Nfld.). Thus, for eggs spawned on St. Pierre Bank in May-June, development to hatching would occur in 15-20 days, whereas those spawned on the northwestern slope of Grand Bank from April to early June would undergo development at slightly lower temperatures than on St. Pierre Bank.

Eggs and larvae from cod spawning on the northwestern slope of Grand Bank drift southward along the western slope of the bank, with some coastward dispersion, and thence westward toward St. Pierre Bank. Eggs and larvae from spawning on St. Pierre Bank and those reaching the bank in the western branch of the Labrador Current are to some degree retained by slow circular currents, but some may be carried by the Labrador Current to the western part of the south coast of Newfoundland. With slightly later spawning on St. Pierre than on southern Grand Bank, temperatures during egg and larval development in both areas are approximately the same, thus accounting for the similar low vertebral means and low percentages of high vertebralcount fish in the samples. Despite the similarity of vertebral means, migration studies showed that St. Pierre Bank and Grand Bank cod do not intermingle to any considerable degree except at the western fringe of the latter stock (Templeman, 1974, 1979; Templeman and Fleming, 1962). Thus, although the vertebral numbers in St. Pierre Bank cod are distinctly lower than in the Labrador-East Newfoundland stock, this meristic character is not useful for delineating the St. Pierre Bank and southern Grand Bank stocks.

Many of the sampels from the area inhabited by the populations comprising the Avalon stock complex had vertebral means intermediate between the high and low vertebral-count fish of the northern and southern stocks respectively. Some of the eggs and larvae produced in this area, especially those from early spawning eastward of the Avalon Peninsula may develop 
under less favorable conditions and thus have higher vertebral numbers than cod on St. Pierre Bank. However, it is more likely that most of the samples with these intermediate vertebral means indicate intermingling of cod from the northern and southern stocks, as reflected by the declining proportions of high vertebral-count fish south of St. John's and as shown by migration studies (Templeman, 1974, 1979).

Northern Guif-western South Coast of Newfoundland stock complex. The northern Gulf cod stock lives in the Gulf of St. Lawrence north of the Laurentian Channel from spring to autumn and spawns in the northern part of the Gulf from March to September, with peak spawning in May-early June (Templeman, 1979). The larger fish of this stock migrate in winterearly spring southward along western Newfoundland to intermingle with the western South Coast stock on the north side of Cabot Strait and along the western part of the south coast of Newfoundland. The western South Coast stock spawns in April to June, mostly late April and May, along the coast from Port aux Basques to Hermitage and Fortune bays, and on Rose Blanche and Burgeo banks. Many cod of this small stock migrate in summer to the northern part of the Gulf while others remain close to their wintering areas along the south coast.

From temperature charts utilizing observations from 1914 to 1948 (Lauzier et al., 1957), average surface temperatures in the northern part of the Gulf of St. Lawrence (Div. 4R and 4S) were $1^{\circ}$ to $5^{\circ} \mathrm{C}$ in May, $2^{\circ}$ to $7^{\circ} \mathrm{C}$ in June, and $5^{\circ}$ to $18^{\circ} \mathrm{C}$ in July-September. At these surface temperatures, with peak spawning in May-June, hatching probably occurs in about 20 days and more rapidly for later spawning. However, the temperatures at $50 \mathrm{~m}$ were $-1^{\circ}$ to $2^{\circ} \mathrm{C}$ in May and $0^{\circ}$ to $1^{\circ} \mathrm{C}$ in August, indicating that the average time to hatching would be considerably longer for eggs drifting in the subsurface layers.

In the Gulf of St. Lawrence north of the Laurentian Channel, there is a general anticlockwise circulation with some large eddies which help to retain the larvae in the area. Water enters the Gulf on the northern side of Cabot Strait and there are weak currents flowing out of the Gulf on the southern side of the Strait of Belle Isle and inward on the northern side (El-Sabh, 1975; Trites, MS 1971; Templeman, 1966). At least in late spring and early summer, there are strong drifts of surface water from south to north across the Laurentian Channel (Trites, MS 1971; Messieh, MS 1974). These currents should carry many codeggs and larvae from the southern Gulf stock into the area occupied by the northern Gulf stock. Similarly, some eggs and Iarvae of the northern Gulf stock must be carried in the westward-flowing current north of Anticosti Island to enter the area of the southern Gulf stock by way of the eastward-flowing Gaspe Current. However, there is no considerable migration of adult cod north or south across the Laurentian Channel except at the western extremity of the two stocks (Mckenzie, 1956; McCracken, 1959; Jean, 1963; Martin and Jean, 1964; Marcotte, MS 1965; Templeman, 1974, 1979).

Most of the spawning of cod in the northern Gulf and along the western part of the south coast of Newfoundland occurs in late spring and early summer, and temperatures for egg and early larval development are high enough that most of the fish have low vertebral numbers similar to those of the southern Grand Bank stock. The similarity is merely coincidental because migration studies have indicated no significant exchange between these stocks (Templeman, 1974, 1979; Templeman and Fleming, 1962).

In the northeastern part of the Gulf near and in the Strait of Belle Isle, some samples with high vertebral means indicate incursion of schools of the LabradorEast Newfoundland stock and samples with intermediate vertebral means reflect a mixture of fish of that stock with low vertebral-count fish of the northern Gulf stock. This interrelationship is evident also from migrations of tagged cod (Templeman, 1974, 1979).

Southern Gulf stock. The mature and large immature cod of this stock, which inhabits the area south of the Laurentian Channel, migrate eastward in winter to and outside of Cabot Strait along the southern side of the Channel and return in late spring and summer to spawn in the Gulf, with the greatest concentrations in the Chaleur Bay-Gaspé area (Powles, 1958; Templeman, 1962b; Martin and Jean, 1964). Spawning occurs from May to September, with peak spawning in late June (Powles, 1958) or in late May-early June (Halliday and Pinhorn, MS 1980).

According to Lauzier et al. (1957), surface temperatures in the southern Gulf of St. Lawrence (Div. 4T) range from $1^{\circ}$ to $8^{\circ} \mathrm{C}$ in May, $6^{\circ}$ to $12^{\circ} \mathrm{C}$ in June, and $11^{\circ}$ to $19^{\circ} \mathrm{C}$ in July-September. Average temperatures at $50 \mathrm{~m}$ were $-1^{\circ}$ to $2^{\circ} \mathrm{C}$ in May and $0^{\circ}$ to $5^{\circ} \mathrm{C}$ in August. Brunel (1970), for six stations off Chaleur Bay, reported that mean surface temperatures in 1960-62 were $3.4^{\circ}$ to $6.0^{\circ} \mathrm{C}$ in May, $6.5^{\circ}$ to $12.9^{\circ} \mathrm{C}$ in June, and $10.9^{\circ}$ to $16.3^{\circ} \mathrm{C}$ in July-September. At these temperatures, with peak spawning in May-June, hatching probably occurs in 10 days or less after spawning but eggs lying below the surface layer would develop more slowly. As for the northern Gulf stock, most of the spawning in this stock is so late in the season and the temperatures high enough to produce the low vertebral numbers typical of both Gulf stocks.

Water circulation in the southern Gulf of St. Lawrence involves mainly the Gaspé Current which flows 
southeastward over the Magdalen Shallows to emerge from the Gulf on the southern side of Cabot Strait as the Cape Breton Current (El-Sabh, 1975; Trites, MS 1971; Templeman, 1966), and some of the larvae may be carried out of the Gulf to settle as juveniles later in the year on the northern part of the Scotian Shelf. The migrations of occasional adult cod north or south across the Laurentian Channel as indicated from various tagging studies (noted above in discussing the northern Gulf stock), the influx of some larvae from the northern Gulf stock around the western end of Anticosti Island, and the possible interchange of larvae north and south of the Channel due to occasional surface drift prevent great genetic differences from being established between the northern and southern Gulf stocks. Also, the temperature conditions during egg and larval development are similar enough that differences between the average vertebral numbers of the northern and southern stocks are not great.

Scotian Shelf and Georges Bank stocks. The cod populations in these areas spawn progressively earlier from north to south. On the Scotian Shelf, spawning occurs during March-June, with peak spawning in May on Banquereau, in April on Sable Island and Emerald banks and in late March on Browns Bank (McKenzie, 1956; Templeman, 1962b). On the eastern part of Georges Bank, cod spawn during February-April with a peak in late February (Templeman, 1962b).

Surface temperatures in mid-A pril 1970 on Banquereau (where peak spawning is in May) were $2^{\circ}$ to $3^{\circ} \mathrm{C}$ (L'Herrou and Minet, 1971), and in 1958-60 on Emerald Bank (where peak spawning is in April) they were $1^{\circ}$ to $5^{\circ} \mathrm{C}$ in late February, $6^{\circ}$ to $7^{\circ} \mathrm{C}$ in April and $4^{\circ}$ to $10^{\circ} \mathrm{C}$ in May (Martin, 1959, 1960, 1961). Examples of surface temperatures over Browns Bank (where peak spawning is in March) were $3^{\circ} \mathrm{C}$ in February 1969 (Light and Henderson, 1974$)$, and $2.0^{\circ} \mathrm{C}$ in mid-March, $3.6^{\circ} \mathrm{C}$ in mid-April, and $7^{\circ}$ to $9^{\circ} \mathrm{C}$ in mid-June 1920 (Bigelow, 1927). On northeastern Georges Bank (where peak spawning is in February), surface temperatures were $4^{\circ}$ to $7^{\circ} \mathrm{C}$ in February 1969 (Light and Henderson, 1974 ), and $3.1^{\circ}$ to $3.6^{\circ} \mathrm{C}$ in early March, $3.9^{\circ}$ to $4.0^{\circ} \mathrm{C}$ in mid-April, and $9^{\circ}$ to $10^{\circ} \mathrm{C}$ in mid-June 1920 (Bigelow, 1927). In winter and early spring, the temperature of coastal water is usually lower than that on the offshore banks in the same latitude.

The current drift over the Scotian Shelf is generally southwestward, much of the flow being derived from the Cape Breton Current (McLellan, 1957), but there are indications of various circular movements (Hachey, 1947). Eggs spawned over various parts of the shelf tend to drift southwestward, encountering higher temperatures as they proceed. The southwesterly current drift joins the anticlockwise gyre of the Gulf of Maine from which a clockwise current flows around the northern part of Georges Bank (Bigelow, 1927). Most of the eggs and larvae from spawning on the Scotian Shelf may be retained by slow circular eddies around the various bank areas, but some larvae are probably carried into the Gulf of Maine and eventually to the Georges Bank area. Walford (1938) reported that haddock eggs from Georges Bank spawning in 1931 and 1932 developed there with no evidence of a southwesterly drift. Larvae drifted in a southwesterly direction but were generally common over the bank. The distributions on the bank of late stage haddock and cod eggs were generally similar. However, Colton (1958) concluded that the majority of the haddock eggs produced on Georges Bank in 1953 drifted off the bank and that the 1953 year-class on Georges Bank was probably the progeny of Browns Bank haddock.

In comparison with temperature conditions during the period of spawning and egg development off Labrador and northeastern Newfoundland, surface-layer temperatures on the Scotian Shelf and Georges Bank during spawning and egg development were considerably higher and undoubtedly account for the lower vertebral numbers in cod of these southern areas. Much more detailed information on temperature at spawning time, egg location during development, and current drift would be needed to explain the relatively small north-south differences in vertebral means from the northern part of the Scotian Shelf southward to Browns Bank and Georges Bank.

McKenzie (1940) reported vertebral means of 52.59-52.84 for autumn-spawning cod from Halifax and vicinity, compared with means of 53.89 and 53.94 for spring-spawning resident fish of the same area, and with the lowest mean (53.76) for the Scotian Shelf in this paper (Fig. 3). The eggs of these autumn spawners developed at about $17^{\circ}$ to $5^{\circ} \mathrm{C}$, apparently at considerably higher temperatures than those of the springspawners.

\section{Summary and Conclusions}

1. There were only relatively small variations in cod vertebral numbers in the same areas of the Northwest Atlantic from the earliest samples collected in 1923-29 to the recent collections in 1947-71.

2. On the average for all data, the vertebral mean for female cod was 0.10 greater than that for males.

3. From data for the $1947-60$ period, high vertebral means, typically above 55 , outlined the location of the Labrador-East Newfoundland cod stock from northern Labrador southward along eastern Newfoundland to the northern part of the Avalon Peninsula and to the northwestern slope of Grand Bank (Div. 2G to $3 \mathrm{~K}$ and the northern part 
of Div. 3L). Data for the 1961-71 period presented essentially the same picture. In both periods, vertebral means of inshore samples from Labrador and eastern Newfoundland (Div. $2 \mathrm{G}$ to $3 \mathrm{~K}$ ) tended to be slightly lower than those of offshore areas.

4. The West Greenland cod stock (Subarea 1) had significantly lower vertebral means that the adjacent Labrador-East Newfoundland stock.

5. The southern Grand Bank stock (Div. 3NO) had the lowest vertebral numbers of the eastern Newfoundland area, typically below but occasionally slightly above 54 .

6. On the northern and western Grand Bank and coastally around the Avalon Peninsula, especially south of St. John's (Div. 3L), vertebral means were intermediate, reflecting mixtures of the northern high vertebral-count, the southern low vertebral-count and the Avalon stocks, as had been previously shown by migration studies. Intermediate vertebral averages were also evident in cod samples from the Flemish Cap.

7. Vertebral means were typically low (around 54) in the northern and southern stocks of the Gulf of St. Lawrence, but intermediate and high vertebral-count samples from the northeastern part of the Gulf indicated incursions of schools of the Labrador-East Newfoundland stock.

8. Vertebral means were similarly low on the Scotian Shelf and Georges Bank, with evidence of a declining trend from north to south, indicating different stocks.

9. The absence of low vertebral numbers and presence of high vertebral numbers offered relatively clear outlines of the Labrador-East Newfoundland stock in contrast to the low proportions of high and the high proportions of low vertebral numbers in the southern stocks on Grand Bank and St. Pierre Bank. Samples from Flemish Cap were different from those of the adjacent northeastern Grand Bank in usually lacking both high and low vertebral numbers.

10. The high vertebral numbers of the Labrador-East Newfoundland stock and the great range of the stock over the area were attributed to spawning mainly off Labrador early in the year, with egg and early larval development in the upper water layers, mostly at temperatures below $0^{\circ} \mathrm{C}$, and with the consequent slow egg and larval development and long drift of the eggs, larvae and fry southward in the Labrador Current.

11. The low vertebral numbers of the southern Grand Bank stock were related to later spawning on the slopes of the bank at higher surface temperatures and consequently a shorter developmental period and shorter drift of eggs and larvae which tend to be retained over the southern Grand Bank by slow circular currents.

12. The intermediate vertebral numbers of the Flemish Cap stock were attributed to early spawning and egg development at intermediate temperatures, compared with those affecting the Labrador-East Newfoundland and the southern Grand Bank stocks, and to the presence of a system of currents around Flemish Cap which in favorable years retains large numbers of larvae on this bank, with little opportunity for mixing with cod larvae from the adjacent Grand Bank and the Northeast Newfoundland Shelf areas.

13. The later spawning in the Gulf of St. Lawrence than off Labrador and the considerably higher surface temperatures produced the typically low vertebral numbers of the northern and southern Gulf stocks, between which there is apparently little intermingling as adults (from tagging studies) but possibly considerable mixing as larvae due to the nature of the current system in the area.

14. In spite of the early spawning of cod on most of the Scotian Shelf and on Georges Bank, surface water temperatures at spawning time are relatively high, compared with those off Labrador, and the vertebral numbers consequently low.

\section{Acknowledgements}

I am grateful to the many biologists and field technicians of the St. John's Biological Station who assisted in obtaining the data used in this paper, especially to T. K. Pitt, A. M. Fleming and the late G. L. Handrigan for checking vertebral counts in the early period of the study, and to A. M. Fleming, A. W. May, R. Wells and A. T. Pinhorn for collecting cod vertebral samples. Among the many technicians who assisted in the collection and processing of the data, I am especially grateful to C.I. Barbour who for many years supervised and checked the vertebral counting, and to S. H. Lee, L. N. Cluett, C. A. Rose, the late M. H. Manuel, J. R. Burt and $C$. R. Riche who assisted greatly in preparing the data for publication.

The following kindly provided cod vertebral samples from their areas: W. F. Royce and the late C. C. Taylor of the Woods Hole Laboratory of the U.S. Fish and Wildlife Service, F. D. McCracken of the St. Andrews Biological Station, and $Y$. Jean of the Station Biologique de St. Laurent. 


\section{References}

APSTEIN, C. 1909. Die Bestimmung des Alters pelagisch lebender Fischeier. Mitt. dtsch. Seefisch., 25: 364-373.

BIGELOW, H. B. 1927. Physical oceanography of the Gulf of Maine. Fish. Bull. U. S., 40: 511-1027.

BOGDANOV, A. S., K. G. KONSTANTINOV, and A.S. NOSKOV. 1965. USSR research report, 1964. ICNAF Redbook 1965, Part II: 105119.

BRANDER, K. 1979. The relationship between vertebral number and water temperature in cod. ICES J. Cons., 38: 286-292.

BRUNEL, P. 1970. The Gaspé cod ecosystem in the Gulf of St. Lawrence. 1. Seasonal and annual trends of physical oceanographic and climatic factors from 1952 to 1962. Nat. Can., 97: 749-781.

BULATOVA, A. Y. 1962. Some data on the distribution of young cod and haddock off Labrador and Newfoundland. ICNAF Redbook 1962, Part III: 69-78.

BUZDALIN, Y. I., and A. A. ELIZAROV. 1962. Hydrological conditions in the Newfoundland banks and Labrador areas in 1960 . In: Soviet Fisheries Investigations in the Northwest Atlantic, VNIRO-PINRO, Moscow, p. 152-168. (Transl. for U. S. Dept. Int. Nat. Sci. Found., Washington, D. C., by Israel Prog Sci. Transl., 1963.)

CHRZAN, F. 1950. Investigations on the Baltic cod.ICES J. Cons., 16: 192-207.

1968. Polish research report, 1967. ICNAF Redbook 1968, Part II: $75-84$

CLARK, J. R. 1959. Sexual maturity of haddock. Trans. Amer. Fish. SOC., 88: 212-213

COLTON, J. B. 1958. Report on studies of fluctuations of year-class strength of haddock. ICNAF Spec. Publ., No. 1: 279.

1965. The distribution and behaviour of pelagic and early demersal stages of haddock in relation to sampling techniques. ICNAF Spec. Publ., No. 6: 317-333.

CORLETT, J. 1958. Distribution of larval cod in the western Barents Sea. ICNAF Spec. Publ., No. 1: 281-288.

CROSS, T. F., and R. H. PAYNE. 1978. Geographic variation in Atlantic cod, Gadus morhua, off eastern North America: a biochemical systematics approach. J. Fish. Res. Bd. Canada, 35: 117-123.

DANNEVIG, A. 1933. The number of vertebrae in Gadus virens $L$. from the Norwegian Skagerak coast. ICES J. Cons., 8: 355-356.

DANNEVIG, $H .1895$. The influence of temperature on the development of the eggs of fishes. Annu. Rep. Fish. Bd. Scotland, No. 13 , Part III: 147-152.

DIAS, M. L. 1965. Portuguese research report, 1964. ICNAF Redbook 1965, Part 11: 95-102.

1967. Portuguese research report, 1966. ICNAF Redbook 1967, Part II: 90-106.

1968. Portuguese research report, 1967. ICNAF Redbook 1968, Part II: $85-91$

1969. Portuguese research report, 1968. ICNAF Redbook 1969, Part II: 76-88.

1971. Portuguese research report, 1970. ICNAF Redbook 1971, Part II: 106-115.

1972. Portuguese research report, 1971. ICNAF Redbook 1972, Part 11: 71-78

DIETRICH, G. 1960. Temperatur-, Salzgehalts- und SauerstoffVerteilung auf den Schnitten von F.F.S. Anton Dohrn und V.F.S. Gauss im internationalen Geophysikalichen Jahr 1957-1958. Dtsch. Hydrogr. Z. Ergaenzungsh. [ (4)] Hamburg, No. 4, $103 \mathrm{p}$.

EARLL, R. E. 1880. A report on the history and present condition of the shore cod-fisheries of Cape Ann. Mass., together with notes on the natural history and artificial propagation of the species. Rep. U.S. Comm. Fish. and Fisheries for 1878: 685-740.

EL-SABH, M. I. 1975. Transport and currents in the Gulf of St. Lawrence. Rep. Bedford Inst. Oceanogr., Ser. BI-R-75-9, $180 \mathrm{p}$.

FLEMING, A. M. 1958. Differentiation of cod groups in the Newfoundland and Labrador region (Abstract). ICNAF Spec. Publ., No. 1: 331.
1960. Age, growth and sexual maturity of cod (Gadus morhua L.) in the Newfoundland area, 1947-50. J. Fish. Res. Bd. Canada, 17: $775-809$.

MS 1963. Baby cod survey, 1962. Fish. Res. Bd. Canada, Rep. Biol. Sta. St. John's, Newfoundland for 1962-63, App. No. 5.

FOWLER, J. A. 1970. Control of vertebral number in teleosts - an embryological problem. Quart. Rev. Biol., 45: 148-167.

HACHEY, H. B. 1947. Water transports and current patterns for the Scotian Shelf. J. Fish. Res. Bd. Canada, 7: 1-16.

HALLIDAY, R. G., and A. T. PINHORN. MS 1980. The groundfish resource in the Gulf of St. Lawrence. Gulf Groundfish Seminar, 23-25 Sept. 1980

HANSEN. P. M. 1949. Studies on the biology of the cod in Greenland waters. ICES Rapp. Procès.-Verb., 123: 1-77. 27-36

1958. Danish research report, 1957. ICNAF Annu. Proc., 8:

HERMANN, F., P. M. HANSEN, and SV. Aa. HORSTED. 1965. The effect of temperature and currents on the distribution and survival of cod larvae at West Greenland. ICNAF Spec. Publ., No. 6: 389-395.

HILL, H. W., P. G. W. JONES, J. W. RAMSTER, and A. R. FOLKARD. 1975. The current system east of Newfoundland Grand Bank. ICNAF Spec. Publ., No. 10: 41-55.

HUBBS, C. L. 1925. Racial and seasonal variation in the Pacific herring, California sardine and California anchovy. Calif. Fish Game Comm., Fish. Bull. 8: 1-23.

HUYER, A., and A. VERNEY. 1975. Temperature, salinity and sigma-t at Station 27 (47 $\left.33^{\circ} \mathrm{N}, 52^{\circ} 35^{\prime} \mathrm{W}\right)$, 1950-1959. Environment Canada, Mar. Env. Data Serv., Tech. Rep., No. 3, 45 p.

ISELIN, C. 1930. A report on the coastal waters of Labrador, based on exploration by the Chance during the summer of 1926. Proc. Amer. Acad. Arts Sci., 66(1): 1-37.

JAMIESON, A. 1975. Enzyme types of Atlantic cod stocks on the North American banks. In: Isoenzyme IV, Genetics and Evolution. Academic Press, San Francisco, p. 491-515.

JEAN, Y. 1963. Where do Seven Islands cod come from? Dep. Fish. Canada, Trade News, Aug. 1963, p. 6-7.

KIILERICH, A. B. 1939. A theoretical treatment of the hydrographical observation material. Godthaab Expedition, 1928. Medd. om Grönland, 78(5): 1-149.

KUDLO, B. P., and V. V. BURMAKIN. 1972. Water circulation in the south Labrador and Newfoundland areas in 1970-1971. ICNAF Redbook 1972, Part III: 27-33.

KUDLO, B. P., V.V. BURMAKIN, and V.S. STERKHOV. 1980. Geostrophic circulation of Northwest Atlantic waters from Davis Strait to Newfoundland, generalized from 1962 to 1978 data. ICNAF Sel. Papers, No. 6: 53-54.

LAUZIER, L., R. W. TRITES, and H. B. HACHEY. 1957. Some features of the surface layer of the Gulf of St. Lawrence. Bull. Fish. Res. Bd. Canada, No. 111: 195-212.

LEAR, W. H., R. WELLS, and W. TEMPLEMAN. MS 1979. The discreteness of the Flemish Cap cod stock. ICNAF Res. Doc., No. 76, Serial No. 5418 .

L'HERROU, R., and J. P. MINET. 1971. Environmental studies in ICNAF Div. 3P and $4 \mathrm{~V}$ in spring 1970. ICNAF Redbook 1971, Part III: 29-48.

LIGHT, M., and S. J. HENDERSON. 1974. Oceanography in the Gulf of Maine and adjacent waters in support of the international Commission for the Northwest Atlantic Fisheries: January 1968; January-February 1969. U. S. Coast Guard Oceanogr. Rep., No. CG 373-65, p. 1-91.

LINDSEY, C. C. 1954. Temperature-controlled meristic variations in the paradise fish, Macropodus opercularis (L.). Can. J. Zool., 32 : 87-98.

1961. The bearing of experimental meristic studies on racial analysis of fish populations. Proc. 9th Pacific Sci. Congress, Bangkok, 1957, p. 54-58.

1962a. Experimental study of meristic variations in a population of threespine sticklebacks, Gasterosteus aculeatus. Can. J. Zool., 40: 271-312. 
$1962 b$. Observations on meristic variation in ninespine sticklebacks, Pungitius pungitius, reared at different temperatures. Can. J. Zool, 40: 1237-1247.

MANKEVICH, E. M., and V. S. PROKHOROV. 1962. Size-age compositions and spawning of the cod on the southwestern slope of Flemish Cap Bank. In: Soviet Fisheries Investigations in the Northwest Atlantic, VNIRO-PINRO, Moscow, p. 349-354. (Transl. for U. S. Dept. Interior, Nat. Sci. Found., Washington, D. C., by Israel Prog. Sci. Transi., 1963.)

MARCOTTE, A. MS 1965. Equitage de morues dans la région d'Anticosti. Rapp. Annu. Stn. Biol. Mar. Grand-Rivière, 1964, p. 85-88.

MARTIN, W. R. 1953. Identification of major groundfish stocks in Subarea 4 of the Northwest Atlantic Convention Area. ICNAF Annu. Proc., 3: 57-61. $26-31$

1959. Canadian research report, 1958. ICNAF Annu. Proc., 9:

1960. Canadian research report, 1959. ICNAF Annu. Proc., 10: 25-31.

1961. Canadian research report, 1960. ICNAFAnnu. Proc., 11: $31-37$

MARTIN, W. R., and Y. JEAN. 1964. Winter cod taggings off Cape Breton and on offshore Nova Scotia banks, 1959-62. J. Fish. Res. Bd. Canada, 21: 215-238.

MAY, A. W. 1965. The validity of otolith ages of southern Grand Bank cod. ICNAF Res. Bull., No. 2: 19-24.

MCCRACKEN, F. D. 1959. Cod tagging off northern New Brunswick in 1955 and 1956. Fish. Res. Bd. Canada, Atlant. Prog. Rep., No. 72 : 8-17.

McHUGH, J. L. 1942. Vertebral number of young herring in southern British Columbia. J. Fish. Res. Bd. Canada, 5: 474-484.

MCKENZIE, R. A. 1939. A change in the spring-summer cod fishery of eastern Cape Breton, N. S. Fish. Res. Bd. Canada, Atlant. Prog Rep., No. 25: 3-5.

1940. Nova Scotian autumn cod spawning. J. Fish. Res. Bd. Canada, 5: 105-120

1956. Atlantic cod tagging off the southern Canadian mainland. Bull. Fish. Res. Bd. Canada, No. 105, 93 p.

MCKENZ!E, R. A., and G. F. M. SMITH. 1955. Atlantic cod populations along the southern Canadian mainland as shown by vertebral count studies. J. Fish. Res. Bd. Canada, 12: 698-705.

MCLAREN, I. A. 1967. Introduction to biological studies of Ogac Lake a landlocked fiord on Baftin Island. J. Fish. Res. Bd. Canada, 24 975-980.

McLELLAN, H. J. 1957. On the distinctness and origin of the slope water off the Scotian Shelf and its easterly flow south of the Grand Banks. J. Fish. Res, Bd. Canada, 14: 213-239.

MESSIEH, S. N. MS 1974. Surface and bottom currents in the Gulf of St Lawrence, as inferred from recoveries of drift-bottles and sea-bed drifters released in 1967-68. Fish. Res. Bd. Canada, MS Rep. Ser., No. 1287,25 p.

MEYER, A. 1962. German research report, 1961. ICNAF Redbook 1962 Part II: 55-61.

1967. The estimation of efficient use of West Greenland cod stocks, a simple method of showing how a fishery should be carried out to get the highest output from the fish stocks. ICNAF Redbook 1967, Part III: 3-21.

MOLANDER, A. R., and M. MOLANDER-SWEDMARK. 1957. Experimental investigations on variation in plaice (Plouronectes platessa Linné). Rep. Inst. Mar. Res., Lysekil, (Biol.), No. 7, 45 p.

MONTEIRO, R., and M. L. DIAS. 1964. Portuguese research report, 1963. ICNAF Redbook 1964, Part III: 70-85

MOVCHAN, O. A. 1967. Phytoplankton distribution and development in the Newfoundland area in relation to seasonal variation of some abiotic factors. Akad. Nauk USSR Oceanology, 7(6): 820-831. (Transl. by Scripta Technica for the American Geophysical Union.)

NOSKOV, A. S., and G. P. ZAKHAROV. 1964. Soviet research report, 1963. ICNAF Redbook 1964, Part II: 92-112.

NOSKOV, A. S., G. P. ZAKHAROV, and I. N. SIDORENKO. 1963. USSR research report, 1962. ICNAF Redbook 1963, Part II: 79-101.
PATAIQUIN, D. G. 1967. Biology of Gadus morhua in Ogac Lake, a landlocked fiord on Baffin Island. J. Fish. Res. Bd. Canada, 24 2573-2594

PINHORN, A. T. 1970. Fishery and biology of Atlantic cod (Gadus morhua) off the southwest coast of Newfoundland. J. Fish. Res. Bd. Canada, 26: 3133-3164.

POSTOLAKY, A. 1. 1962. Biology of the Labrador and Newfoundland cod. In: Soviet Fisheries Investigations in the Northwest Atlantic, VNIRO-PINRO, MOscow, p. 338-348. (Transi. for U. S. Dept. Int.

Nat. Sci. Found., Washington, D. C., by Israel Prog. Sci.Transl. 1963.)

MS 1975. Distribution and abundance of codeggs in the South Labrador and Newfoundland areas in 1974. ICNAF Res. Doc., No. 101, Serial No. 3593

POWLES, P. M. 1958. Studies of reproduction and feeding of Atlantic cod (Gadus callarias L.) in the southwestern Gulf of St. Lawrence. J. Fish. Res, Bd. Canada, 15: 1383-1402.

RAITT, D. S. 1933. The fecundity of the haddock. Fish. Bd. Scotland Sci. Invest. 1932, No. 1, $42 \mathrm{p}$.

RASMUSSEN, B. 1959. On the migration pattern of the West Greenland stock of cod. ICES Ann. Biol, , 4: 123-124.

RODRIGUEZ, O. 1956. Spanish research report, 1955. ICNAF Annu Proc. 6: $55-57$

RODRIGEUZ, O., AND A. ROJO. 1955. Report on the cruise of the Spanish trawler Mistral in the waters off Newfoundland, June-July 1954. ICNAF Annu. Proc., 5: 51-57.

ROUNSEFELL, G. A, and E. H. DAHLGREN. 1932. Fluctuations in the supply of herring, Clupea pallasii, in Prince William Sound, Alaska. Bull. U. S. Bur. Fish., 47: 262-291.

SCHMIDT, J. 1921. Laboratory experiments with the common trout (Salmo trutta L.) In: Racial Investigations VII, C. R. Lab. Carlsberg, 14(15): 19-24

1930. The Atlantic cod (Gadus callarias L.) and local races of the same. In: Racial Investigations X, C. R. Lab. Carlsberg, 18(6): $1-71$

SEREBRYAKOV, V.P. 1965. Some results of Soviet research work on ichthyoplankton in the Northwest Atlantic: eggs and larvae of cod. ICNAF Spec. Publ., No. 6: 425-433.

MS 1965. Cod spawning in Greenland waters. ICNAF Res. Doc., No. 67, Serial No. 1535.

1967. Cod reproduction in the Northwest Atlantic. Trudy PINAO, 20: 205-242. (Fish. Res. Bd. Canada Transi. Ser. No. 1133, 1968.)

MS 1978. Ichthyoplankton from the Flemish Cap Bank. ICNAF Res. Doc., No. 18, Serial No. 5172.

SEYMOUR, A. 1959. Effects of temperature upon the formation of vertebrae and finrays in young chinook salmon. Trans. Am. Fish. Soc., 88: 58-69.

SMITH, E. H. 1931. Arctic ice, with especial reference to its distribution in the North Atlantic Ocean. The Marion Expedition to Davis Strait and Baffin Bay, 1928. Scientific results. Bull. U. S. Cst. Guard, No 19(3), $221 p$

SMITH, E. H., F. M. SOULE, and O. MOSBY. 1937. Physical oceanography. The Marion and General Greene expeditions to Davis Strait and Labrador Sea, 1928-1931-1933-1934-1935. Scientific results. Bull. U. S. Cst. Guard, No. 19(2), 259 p.

SOKAL, R. R., and F. J. ROHLF. 1969. Biometry. The principles and practice of statistics in biological research. W. H. Freeman and Co., San Francisco, U. S. A., 776 p.

SONINA, M. A. 1969. Biology of the Arcto-Norwegian haddock during 1927-1965. Trudy PINRO, 26: 3-111, 115-124. (Fish. Res. Bd. Canada, Transl. Ser. No. 1924,1971 .)

STANEK, E. MS 1968. The number of rays in the second dorsal fin and the number of vertebrae in cod from Labrador, Newfoundland and Nova Scotia. ICNAF Res. Doc., No. 71, Serial No. 2058

TÅNING, A. V. 1937. Some features in the migration of cod. ICES J. Cons., 12: 3-35

1944. Experiments on meristic and other characters in fishes 1. On the influence of temperature on some meristic characters in seatrout and the fixation-period of these characters. Medd. Danm. 
Fisk.-og Havunders. N. S., 11(3): 1-66.

1952. Experimental study of meristic characters in fishes. Biol. Rev., 27: 169-193.

TEMPLEMAN, W. 1953. Knowledge of divisions of stocks of cod, haddock, redfish, and American plaice in Subareas 3 and 2 of the Northwest Atlantic Convention Area. ICNAF Annu. Proc., 3: 62-66. 1959. Canadian research report, 1958. A. Subareas 2 and 3. ICNAF Annu. Proc., 9: 20-26.

1961. Redfish distribution off Baffin Island, northern Labrador and in Ungava Bay in August-September 1959. ICNAF Spec. Publ., No. 3: 157-162.

1962a. Canadian research report, 1961. A. Subareas 2 and 3. ICNAF Redbook 1962, Part II: 3-20.

1962b. Divisions of cod stocks in the Northwest Allantic. ICNAF Redbook 1962, Part III: 79-129.

1964. Canadian research report, 1963. A. Subareas 2 and 3. ICNAF Redbook 1964, Part II: 3-21.

1965. Canadian research report, 1964. A. Subareas 2 and 3. ICNAF Redbook 1965, Part II: 3-20.

1966. Marine resources of Newfoundland. Bull. Fish. Res. Bd. Canada, No. 154, $170 \mathrm{p}$

1969. Canadian research report, 1968. A. Subareas 1, 2 and 3. ICNAF Redbook 1969, Part II: 3-13.

1973. Temperatures and salinities in the eastern Newfoundland area in 1972. ICNAF Redbook 1973, Part III: 19-25.

1974. Migrations and intermingling of Atlantic cod (Gadus morhua) stocks of the Newfoundland area. J. Fish. Res. Bd. Canada, 31: 1073-1092.

1975. Comparisons of temperatures in July-August hydrographic sections of the eastern Newfoundland area in 1972 and 1973 with those from 1951 to 1971. ICNAF Spec. Publ., No. 10:12-31. 1976. Biological and oceanographic background of Flemish Cap as an area for research on the reasons for year-class success and failure in cod and redfish. ICNAF Res. Bull., No. 12: 91-117. 1979. Migrations and intermingling of stocks of Atlantic cod, Gadus morhua, of the Newfoundland and adjacent areas from tagging in 1962-66. ICNAF Res. Bull., No. 14: 5-50.

TEMPLEMAN, W., and C. A. BISHOP. 1979a. Sexual maturity and spawning in haddock, Melanogrammus aeglefinus, of St. Pierre Bank. ICNAF Res. Bull., No. 14: 77-83.

1979b. Age, growth, year-class strength, and mortality of haddock, Melanogrammus aeglefinus, on St. Pierre Bank in 1948-75 and their relation to the haddock fishery of this area. ICNAF Res. Bull., No. 14: 85-89.

TEMPLEMAN, W., and A. M. FLEMING. 1962. Cod tagging in the Newfoundland area during 1947 and 1948. J. Fish. Ros. Bd. Canada, 19: 445-487.

1963. Distribution of Lernaeocera branchialis (L.) on cod as an indicator of cod movements in the Newfoundland area. ICNAF Spec. Publ., No. 4: 318-322.

TEMPLEMAN, W., V. M. HODDER, and A. M. FLEMING. 1976. Infection of lumpfish (Cyclopterus lumpus) with larvae and of Atlantic cod (Gadus morhua) with adults of the copepod, Lernaeocera branchi- alis, in and adjacent to the Newfoundland area, and inferences therefrom on inshore-offshore migrations of cod. J. Fish. Res. Bd. Canada, 33: 711-731.

TEMPLEMAN, W., V. M. HODDER, and R. WELLS. 1978a. Age, growth, year-class strength and mortality of the haddock, Melanogrammus aegiefinus, on the southern Grand Bank and their relation to the haddock fishery of this area. ICNAF Res. Bull., No. 13: 31-52.

1978b. Sexual maturity and spawning in haddock, Melanogrammus aeglefinus, of the southern Grand Bank. ICNAF Res. Bull., No. 13: 53-65.

TEMPLEMAN, W., and A. W. MAY. 1965. Research vessel catches of cod in the Hamilton Inlet Bank area in relation to depth and temperature. ICNAF Spec. Publ., No. 6: 149-165.

TEMPLEMAN, W., and T. K. PITT. 1961. Vertebral numbers in redfish, Sebastes marinus (L.), in the Northwest Atlantic, 1947-1954. ICES Rapp. Procès.-Verb., 150: 56-89.

TEMPLEMAN, W., H. J. SQUIRES, and A. M. FLEMING. 1957. Nematodes in the fillets of cod and other fishes in Newfoundland and neighbouring areas. J. Fish. Res. Bd. Canada, 14: 831-897.

TESTER, A. L. 1937. Populations of herring (Clupea pallasii) in the coastal waters of British Columbia. J. Biol. Bd. Canada, 3: 108-144.

1938. Variation in the mean vertebral count of herring (Clupea pallasii) with water temperature. ICES J. Cons., 13: 71-75.

THOMPSON, H. 1943. A biological and economic study of cod (Gadus Callarias L.) in the Newfoundland area. Nfld. Dep. Nat. Resour. Fish. Bull., No. 14, 160 p

THOMPSON.W.F. 1917. A contribution to the life-history of the Pacific herring: its bearing on the condition and future of the fishery. Rep. Comm. Fish. B. C. for 1916: 39-87.

THUROW, F. 1970. Über die Fortpflanzung des Dorsches, Gadus morhua L., in der Kieler Bucht. Ber. dtsch. Komm. Meeresforsch, 21 $171-192$

TRAVIN, V.I. 1959. USSR research report, 1958. ICNAFAnnu. Proc., 9: $81-85$

TRITES, R. W. MS 1971. The Gulf as a physical oceanographic system. Proc. 2nd Gulf of St. Lawrence Workshop. Bedford Inst. Oceangr., Dartmouth, N. S., Canada, 30 Nov-2 Dec 1970: 32-63.

WALFORD, L. A. 1938. Effect of currents on distribution and survival of the eggs and larvae of the haddock (Melanogrammus aeglefinus) on Georges Bank. Bull. U. S. Bur. Fish., 49(29): 1-73.

WIBORG, K. F. 1948. Investigations of cod larvae in the coastal waters of northern Norway: occurrence of cod larvae, and occurrence of food organisms in the stomach contents and in the sea. Fiskeridir. Skr. (Havunders.), 9(3): 1-27.

1950. The occurrence of fish eggs and larvae along the coast of northern Norway during April-June 1948 and 1949. ICES Ann. Biol., 6: 12-16.

WISE, J.P. 1963. Cod groups in the New England area. Fish. Bull., U. S., 63: $189-203$.

WISE, J. P., and A. C. JENSEN. MS 1960. Stocks of the important commercial species of the ICNAF Convention Area. ICNAF Res. Doc., No. 25, Serial No. 743. 
